\title{
Discogenic Low Back Pain: A Topical Review
}

\author{
Damian Ong ${ }^{1}$, Nicholas HL Chua ${ }^{2 *}$ and Kris Vissers ${ }^{3}$ \\ ${ }^{1}$ Department of Anaesthesiology, Tan Tock Seng Hospital, Singapore \\ ${ }^{2}$ Specialist Pain International Clinic, Singapore \\ ${ }^{3}$ Department of Anesthesiology, Radboud University Medical Centre, Netherlands
}

Submission: January 18, 2018; Published: February 26, 2018

*Corresponding author: Damian Ong, Department of Anaesthesiology, Intensive Care and Pain Medicine, Tan Tock Seng Hospital, 11 Jalan Tan Tock Seng, Singapore 308433, Tel: +65 98163454,_Email: damian_wk_ong@ttsh.com.sg

\section{Abstract}

Background: Discogenic low back pain (LBP) is a significant medical condition that carries a heavy socioeconomic burden. The pathophysiology, diagnosis and treatment modalities are reviewed in this article.

Methods: A review of the English literature addressing discogenic LBP in PubMed until 2015 is undertaken.

Results: The various methods of confirming the diagnosis of discogenic pain is elucidated in this article. With regards to the effectiveness of percutaneous treatments, intradiscal methylene blue (MB) and biacuplasty have a weakly positive recommendation. The evidence for intradiscal electrothermal therapy (IDET) is equivocal. Nucleoplasty, intradiscal pulsed radiofrequency (pRF) and rami communicans radiofrequency (RF) have too few studies to allow them to be assessed. Intradiscal RF, steroids, DiscTRODE and L2 block/RF have negative recommendations.

Conclusion: More evidence is needed for to allow for a better assessment of the effectiveness of treatment for discogenic pain. Future studies need to adhere to the IASP definition of discogenic pain.

Keywords: Low Back Pain; Intradiscal; Intradiscal Electrothermal Annuloplasty; Radiofrequency; Discogram; Back Pain

\section{Introduction}

Chronic Low back pain (LBP) remains a significant medical problem and is a major cause of disability worldwide. In a study published in 2014, the global age-standardized point prevalence of LBP was $9.4 \%$, with it being higher in men at $10.1 \%$ compared with women at $8.7 \%$ [1]. The prevalence increases with age, peaking at 80 years old with a prevalence of up to $40 \%$ in males and $35 \%$ in females. In a retrospective chart review by Depalma et al. [2], the intervertebral disc contributed to $41.8 \%$. The aim of this topical review is to give an overview on the pathophysiology, diagnosis and the evidence for the various treatment modalities for discogenic pain. A search in Pubmed for English articles up to 2015 was used to provide the literature contained in this review.

\section{Pathophysiology}

From the rationale that a structure must have a sensory nerve supply for it to be capable of causing pain, the innervation of the intervertebral disc has been extensively studied and documented. Bogduk described the innervation of the lumbar intervertebral disc in 1980 [3]. The anterior and lateral portions of the annulus fibrosis (AF) are supplied by branches of the grey rami communicantes of the sympathetic trunk. The posterior aspect of the AF is supplied by the sinuvertebral nerve, which is a combination of a branch from the ventral ramus and a branch of the grey ramus communicantes of the corresponding segment.

In a normal disc, only the outer one third of the AF is innervated. However, in patients with discogenic pain, it is found that there is innervation all the way into the inner third of the $\mathrm{AF}$ and even into the nucleus pulposus (NP) [4-6]. The tears in the $\mathrm{AF}$, which are commonly in the posterior part, caused the formation of a vascularized granulation tissue starting from the outer part of the AF into the disc. Within this granulation tissue, nerve fibers are found and these abnormal nerves are the likely cause for the nociception of the intervertebral disc [7]. In addition to the abnormal sensory innervation described above, inflammation within the intervertebral disc has also been implicated in the pathogenesis of discogenic pain $[8,9]$.

\section{Definition of Discogenic Low Back Pain}

According to the International Association for the Study of Pain (IASP), the definition of lumbar discogenic pain is lumbar spinal pain, with or without referred pain to the lower limb girdle or lower limb, stemming from a lumbar intervertebral disc [10]. 
The diagnosis hinges on the fact that the pain must be shown to be conclusively from the intervertebral disc. This can be done in 3 ways.

i. Selective anesthetization of the putatively symptomatic intervertebral disc completely relieves the patient of the accustomed pain.

ii. Selective anesthetization of the putatively symptomatic intervertebral disc substantially relieves the patient of the accustomed pain for a period consonant with the expected duration of the local anaesthetic used.

iii. Provocation discography of the putatively symptomatic intervertebral disc reproduces the patient's accustomed pain but provided that provocation of at least 2 adjacent intervertebral discs clearly does not reproduce the patient's pain.

Of note, none of the above criteria is based on MRI findings. Physiological aging of the intervertebral disc will appear abnormal on MRI even though that disc is not symptomatic [11]. As such, an MRI by itself cannot be used to diagnose the symptomatic disc and the above interventional diagnostic procedures are indicated. Though the IASP states that selective anaesthesia of the disc is a valid method of diagnosing discogenic pain, only a few studies attempt to use selective blockade of the disc [12-17] as part of their inclusion criteria.

\section{Provocative Discography}

The most commonly used method of diagnosing discogenic LBP hinges on a positive provocative discography. The procedure is briefly outlined and the criteria for a diagnosis of discogenic LBP are highlighted. The Spine Intervention Society (SIS), formerly known as the International Spine Intervention Society (ISIS), recommends the following criteria to diagnose discogenic pain during provocative discography [18].

i. Provocation of the suspect disc induces concordant pain.

ii. The pain is at least $7 / 10$ on a numeric rating scale.

iii. The pain is provoked by less than 50 psi over opening pressure.

iv. Provocation of at least 1 adjacent disc does not induce concordant pain.

The rate of infusion should not exceed $0.05 \mathrm{ml} / \mathrm{s}$ as this allows for uniform pressurization within the disc. If too high an infusion rate is used, false positives may occur because of the pressure peaks. These pressure peaks may cause vertebral end plate compression and distention of the adjacent facet joint [19]. The patient should be blinded as to which disc is being stimulated and the disc which is expected to be most painful should be stimulated last.
During provocative discography, the following events should be noted.

i. $\quad$ Opening pressure (OP) which is defined as the pressure in which contrast is first seen entering the disc.

ii. Provocation pressure which is defined as the pressure greater than the OP in which the patient first complains of pain

iii. The peak pressure or final pressure at the end of the procedure which is greater than the OP.

The procedure is terminated if the following is reached.

a. Concordant pain is reproduced to a level of 7 out of 10 on a numeric rating scale

b. The volume injected reaches $3 \mathrm{ml}$ (or up to $4 \mathrm{ml}$ in very degenerated disc in which the pressure remains less than 15psi)

c. The pressure rises to 50 psi above OP in discs with a grade 3 annular tear

d. If contrast leaks through the outer annulus fibrosis or through the endplates in which it might not be possible to pressurize the disc sufficiently to test its sensitivity.

\section{Selective Blockade of the Intervertebral Disc}

The first study to use selective blockade of the disc was performed in 1996 [17]. 1.5-2 milliliters of a mixture of two milliliters of $2 \%$ lignocaine and $1 \mathrm{ml}$ of contrast media were injected into the disc and pain relief was assessed 30 minutes later. Pain relief of $>50 \%$ was judged to be a positive test for discogenic LBP. The same group of authors then used the same criteria in a subsequent study in 2001 [14]. The term "Discoblock" was first used by Ohtori [13]. $0.75 \mathrm{ml}$ of $0.5 \%$ bupivacaine was injected into the intervertebral disc and if pain was reduced thereafter, the diagnosis of discogenic pain was made. This method was then compared to that of conventional provocative discography in patients who underwent surgery based on the diagnosis of discogenic pain obtained from the 2 different diagnostic methods. They found that patients whose diagnosis was obtained from Discoblock were more satisfied with surgery.

2 studies from the same authors on intradiscal pulsed radiofrequency ( $\mathrm{pRF}$ ) used Discoblock in conjunction with provocative discography as part of their inclusion criteria $[15,16]$. They required a $70 \%$ reduction in pain for it to be positive. A modification of this technique is used by Alamin et al. [12] to confirm the diagnosis obtained from provocative discography. In patients who had a positive provocative discography, they inserted a catheter into the nucleus pulposus of the symptomatic disc. They then randomized the patient into either an infiltration of $0.6 \mathrm{ml}$ of $4 \%$ lignocaine or normal saline via the catheter. The results of the 2 nd part of the test were then compared with the 
initial provocative discography findings and the results of the functional disc block and provocative discography were different in $46 \%$ of the patients. This is the only study that has used this protocol and in the absence of a gold standard diagnostic test, it is difficult to comment on its utility as compared to provocative discography.

\section{Interventional Procedures}

\section{Intradiscal Steroids}

Steroids were introduced into the disc to decrease the inflammatory reaction in patients with discogenic pain. As early as the 1960s, clinicians were already introducing steroids into the disc [20]. The last 3 studies published were randomized controlled trials (RCT) and these will be reviewed in this article. In 1992, Simmons et al conducted a randomized double blind active control study (Jadad scoring $=3$, no mention of method of randomization or blinding) [21]. Either methylprednisolone $80 \mathrm{mg}$ (14 patients) or Bupivacaine $7.5 \mathrm{mg}$ (11 patients) was injected intradiscally after a positive single-level provocative discogram. A follow-up of only 10-14 days showed that $21 \%$ of patients who had methylprednisolone injected versus $9 \%$ of bupivacaine reported improvement. There was no statistical superiority in the steroid group.

The RCT by Khot et al. in 2004 (Jadad score $=4$, method of blinding inadequate) compared methylprednisolone $40 \mathrm{mg}$ against $1 \mathrm{ml}$ of normal saline with 60 patients in each group. Only the patient was blinded and follow-up was for 1 year. There was a high loss to FU rate of 14 patients in the steroid group and 8 patients in the saline group. The results of this trial showed no difference between the 2 groups in terms of disability or pain scores. There was a median change of 0 in pain scores in both groups.

Peng et al. [22] published the latest RCT in 2011 in which they looked at patients with positive provocative discography and end plate Modic changes (Jadad score $=4$, method of randomization not stated). They divided the group into 2 based on Modic change Type I or II then subsequently randomized them into 3 treatment groups. The first group received intradiscal saline, the 2nd group intradiscal betamethasone, and the 3rd group intradiscal betamethasone and songmeilie (Chinese herbal medicinal ingredient that reduces inflammation). At 6-month follow-up, in both types of end plate Modic changes, the intradiscal betamethasone and intradiscal betamethasone with songmeilie groups had significant drops in VAS and ODI scores. In contrast to the previous RCTs, intradiscal steroids showed some short-term benefit in patients with discogenic pain and end plate inflammatory changes. This has been suggested in another study [23].

Based on the above RCTs, there is a limited role of intradiscal steroids for patients with discogenic LBP. Older observational studies were not included in this review. Based on the results of the RCTs, only in patients with inflammatory end plate changes would intradiscal steroids have a possibility of short-term benefit and this still needs further clarification with more trials.

\section{Intradiscal Electrothermal Annuloplasty (IDEA)/ Intradiscal Electrothermal Therapy (IDET)}

The IDET procedure utilizes a navigable intradiscal catheter (Spine CATH, Oratec Interventions Inc., Menlo Park, CA, USA) with a 6 -cm active tip that is introduced through a $17 \mathrm{G}$ introducer. The $17 \mathrm{G}$ introducer is inserted into the disc in a similar fashion to performing a discography (Table 1). The flexible catheter is then inserted and it directed to make a loop such that the active tip lies against the posterior AF. In which layer the catheter lies exactly is a matter of debate as some studies state it should lie in the NP-AF junction whereas others say that it should lie within the AF itself [24-26]. It is then postulated that the RF current which is applied across the catheter causes heating of the active tip which ablates the aberrant nociceptive nerve endings in the posterior AF.

In the first observational study, Saal et al. [27] reported that $80 \%$ of the patients had at least a 2 point reduction on VAS with a mean reduction of 3.74 at 7 months follow-up. There were also improvements in analgesic use, SF-36 scores and sitting tolerance. Multiple prospective studies were then published and selected studies are presented in Table 1. Outcomes at 2 years were also published $[25,28]$ and these were in favour of IDET with $57-72 \%$ having a decrease of at least a 2-point decrease in VAS at 2 years. However, several studies showed disappointing results with IDET [29-31] and so there was a need for randomized studies to be performed to better ascertain the utility of IDET.

The first RCT was performed by Pauza et al. [32]. In this well-conducted study, patients either had IDET treatment or a sham procedure. It must be noted that the inclusion criteria for this study required patients to only have a loss of $<20 \%$ of disc height. The results of the study showed that both the placebo and IDET group improved at 6 months but more marked improvement was seen in the IDET group ( $56 \%$ vs. $38 \%$ ). IDET was also more effective in patients who had poorer function preprocedure. Even in this select group of patients with relatively preserved disc height and reasonable function, almost 50\% did not benefit from IDET.

The results from a $2^{\text {nd }}$ RCT were even less impressive. Freedman et al. [33] conducted a placebo controlled trial in which placebo consisted of inserting the introducer needle and the catheter into treatment position but not heating the catheter. They included patients with up to $50 \%$ loss in disc height and patients on worker's compensation. Compared to the Pauza study, the patients had poorer ODI and SF-36 scores. In this study, both the IDET and placebo groups had no improvement at 6 months compared to baseline. It should be noted that in both the RCTs on IDET, the targeted sample size for $80 \%$ power were not reached. 
Table 1: Intradiscal Electrothermal Therapy (IDET).

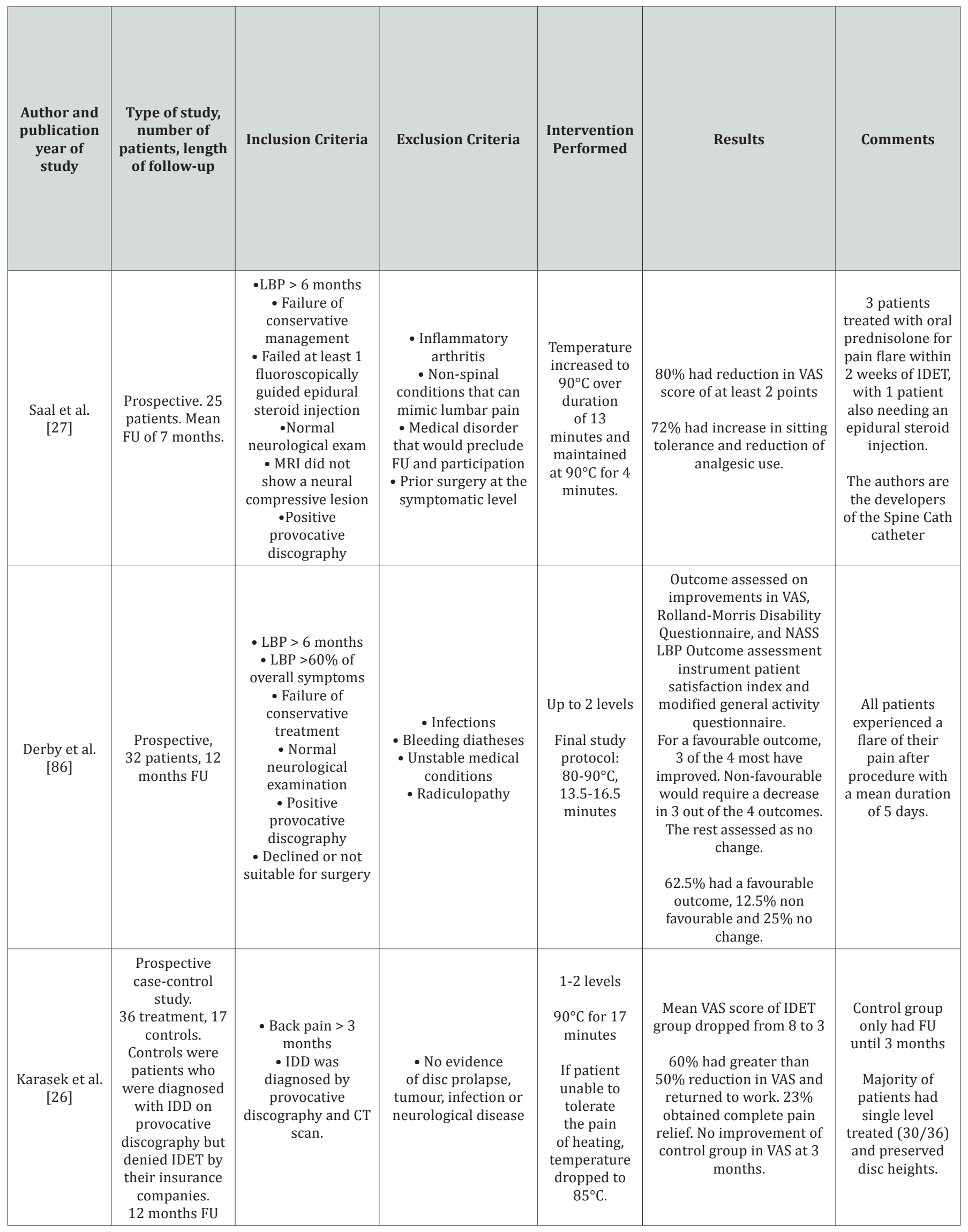




\begin{tabular}{|c|c|c|c|c|c|c|}
\hline $\begin{array}{c}\text { Saal et al. } \\
\text { [87] }\end{array}$ & $\begin{array}{l}\text { Prospective. } \\
62 \text { patients. } 16 \\
\text { months mean } \\
\text { FU. }\end{array}$ & $\begin{array}{c}\bullet \text { LBP }>6 \text { months } \\
\bullet \text { Failure of } \\
\text { conservative } \\
\text { management } \\
\cdot \text { Failed at least } 1 \\
\text { fluoroscopically } \\
\text { guided epidural } \\
\text { steroid injection } \\
\bullet \text { Normal } \\
\text { neurological exam } \\
\bullet \text { MRI did not } \\
\text { show a neural } \\
\text { compressive lesion } \\
\bullet \text { Positive } \\
\text { provocative } \\
\text { discography }\end{array}$ & $\begin{array}{c}\text { •Inflammatory } \\
\text { arthritis } \\
\text { •Non-spinal } \\
\text { conditions that can } \\
\text { mimic lumbar pain } \\
\text { •Medical disorder } \\
\text { that would preclude } \\
\text { FU and participation } \\
\text { •Prior surgery at the } \\
\text { symptomatic level }\end{array}$ & $\begin{array}{l}30 \text { patients } \\
\text { treated at } \\
1 \text { level, } 24 \\
\text { patients at } 2 \\
\text { levels, and } 8 \\
\text { at } 3 \text { levels. } \\
\\
\text { Temperature } \\
\text { increased to } \\
90^{\circ} \mathrm{C} \text { over } \\
\text { duration } \\
\text { of } 13 \\
\text { minutes and } \\
\text { maintained } \\
\text { at } 90^{\circ} \mathrm{C} \text { for } 4 \\
\text { minutes. }\end{array}$ & $\begin{array}{l}\text { Mean drop of } 3 \text { on VAS } \\
\text { scores } \\
\text { 71-74\% had improvement } \\
\text { in either the SF-36 physical } \\
\text { function, SF-36 bodily pain } \\
\text { or the VAS scores. } \\
\text { 19\% had no improvement } \\
\text { in any score. }\end{array}$ & $\begin{array}{c}\text { No } \\
\text { complications. } \\
\\
\text { Disc space } \\
\text { narrowing of } \\
\text { at least } 30 \% \\
\text { associated with } \\
\text { worse outcome. }\end{array}$ \\
\hline $\begin{array}{c}\text { Gertzen et al. } \\
\text { [89] }\end{array}$ & $\begin{array}{l}\text { Prospective. } \\
23 \text { patients. } 6 \\
\text { months FU. } \\
\\
\text { Prospective, } 27 \\
\text { patients. } 1 \text { year } \\
\text { FU. }\end{array}$ & $\begin{array}{c}\text { - LBP > } 6 \text { months } \\
\text { • Failure of } \\
\text { conservative } \\
\text { management } \\
\text { • Normal } \\
\text { neurological } \\
\text { examination } \\
\text { • No evidence } \\
\text { of nerve root } \\
\text { compression on } \\
\text { examination and } \\
\text { MRI } \\
\text { •Positive } \\
\text { provocative } \\
\text { discography } \\
\text {-Intensity of pain } \\
\text { limiting function } \\
\text { • LBP>6 months } \\
\text { - LBP > leg pain } \\
\text { • Pain with } \\
\text { axial loading } \\
\text { and relieved by } \\
\text { recumbency } \\
\text { •Evidence of } \\
\text { discogenic disc } \\
\text { disease on MRI } \\
\text { (8 patients) } \\
\text { or positive } \\
\text { provocative } \\
\text { discography (19 } \\
\text { patients) } \\
\text { • Failure of non- } \\
\text { surgical therapies } \\
\text { including epidural } \\
\text { steroid treatments }\end{array}$ & $\begin{array}{c}\text { - Inflammatory } \\
\text { arthritis } \\
\text { • Non-spinal } \\
\text { conditions that can } \\
\text { mimic lumbar pain } \\
\text { • Medical disorder } \\
\text { that would preclude } \\
\text { FU and participation } \\
\text { • Evidence of } \\
\text { instability on imaging } \\
\text { studies } \\
\text { • Active infection } \\
\text { • Malignancy } \\
\text { - Metabolic disorder } \\
\text { that would preclude } \\
\text { appropriate FU and } \\
\text { participation }\end{array}$ & $\begin{array}{l}\text { Up to } 2 \text { levels } \\
\text { treated. } \\
\\
16.5 \text { minutes } \\
\text { with final } \\
\text { temperature } \\
\text { of } 80 \text { to } 90^{\circ} \mathrm{C} \text {. } \\
16 \text { patients } \\
\text { had } \\
\text { treatment } \\
\text { at } 1 \text { level, } \\
11 \text { patients } \\
\text { treated at } \\
\text { multiple } \\
\text { levels. } \\
\\
\text { Temperature } \\
\text { increased to } \\
90^{\circ} \mathrm{C} \text { over } 13 \\
\text { minutes and } \\
\text { maintained } \\
\text { for } 4 \text { minutes. }\end{array}$ & $\begin{array}{c}2 \text { lost to FU. } \\
\text { 67\% had greater than 50\% } \\
\text { pain relief. } \\
\text { Statistically significant } \\
\text { increase in standing } \\
\text { and walking time. The } \\
\text { improvement in sitting } \\
\text { did not attain statistical } \\
\text { significance. } \\
\text { Pain scores not collected as } \\
\text { part of study. } \\
\text { 47\% had significant } \\
\text { improvement in SF-36 } \\
\text { scores. } \\
\text { 75\% had improvement in } \\
\text { ODI scores. }\end{array}$ & $\begin{array}{c}\text { No } \\
\text { complications. } \\
\text { No } \\
\text { complications } \\
\text { reported. } \\
\text { Failed IDET } \\
\text { occurred in } 1 \\
\text { patient as the } \\
\text { catheter could } \\
\text { not be inserted } \\
\text { likely because } \\
\text { of scar tissue } \\
\text { from previous } \\
\text { discectomy. }\end{array}$ \\
\hline $\begin{array}{c}\text { Saal et al. } \\
\text { [28] }\end{array}$ & $\begin{array}{l}\text { Longer follow- } \\
\text { up study of the } \\
\text { prospective trial } \\
\text { done above [87]. } \\
\text { Mean FU of } 28 \\
\text { months. }\end{array}$ & - As stated above & - As stated above & $\begin{array}{l}\text { As stated } \\
\text { above }\end{array}$ & $\begin{array}{l}4 \text { of the initial } 62 \text { lost to FU } \\
\text { at }>24 \text { months. } 58 \text { patients } \\
\text { assessed. } \\
72 \% \text { had at least a 2-point } \\
\text { improvement in VAS, } 50 \% \\
\text { had at least } 4 \text { points. } \\
78 \% \text { had at least a } 7 \text {-point } \\
\text { improvement in SF bodily } \\
\text { pain subscale. } \\
\text { Improvements in mean } \\
\text { VAS and SF-36 bodily pain } \\
\text { subscale sustained at } 24 \\
\text { months. }\end{array}$ & $\begin{array}{c}\text { No } \\
\text { complications }\end{array}$ \\
\hline
\end{tabular}




\begin{tabular}{|c|c|c|c|c|c|c|}
\hline $\begin{array}{c}\text { Spruit et al. } \\
{[31]}\end{array}$ & $\begin{array}{l}\text { Prospective. } \\
20 \text { patients. } 6 \\
\text { months FU. }\end{array}$ & $\begin{array}{l}\text { - Degenerative disc } \\
\text { disease } \\
\text { - Affected level } \\
\text { L1-S1 } \\
\text { - Predominant low } \\
\text { back pain } \\
\text { - Intolerance for } \\
\text { sitting } \\
\text { - Neurological } \\
\text { examination } \\
\text { normal } \\
\text { - Conservative } \\
\text { treatment applied } \\
\text { for at least } 6 \\
\text { months and failed. } \\
\text { • Positive } \\
\text { provocative } \\
\text { discography }\end{array}$ & $\begin{array}{l}\text { - Spondylolysis or } \\
\text { spondylolisthesis } \\
\bullet \text { Infection } \\
\text { - Active malignancy } \\
\text { • Pregnancy } \\
\text { - Previous lumbar } \\
\quad \text { surgery }\end{array}$ & $\begin{array}{c}16 \text { patients } \\
\text { treated at } \\
1 \text { level, } 4 \\
\text { patients at } 2 \\
\text { levels } \\
\text { Temperature } \\
\text { slowly } \\
\text { increased to } \\
90^{\circ} \mathrm{C} \text { then } \\
\text { maintained } \\
\text { for } 4 \text { minutes }\end{array}$ & $\begin{array}{l}1 \text { patient lost to FU. } \\
\text { Drop of } 14 \mathrm{~mm} \text { on VAS } \\
\text { ( } \mathrm{p}=0.046) \text { but much } \\
\text { variation noted between } \\
\text { patients. } \\
\text { ODI did not improve } \\
\text { significantly. } \\
\text { SF36 vitality and bodily } \\
\text { pain subscales improved } \\
\text { significantly but not others. }\end{array}$ & $\begin{array}{l}\text { No } \\
\text { complications } \\
\text { reported. }\end{array}$ \\
\hline $\begin{array}{c}\text { Bogduk et al. } \\
\text { [25] }\end{array}$ & $\begin{array}{l}\text { Longer term } \\
\text { outcomes of } \\
\text { the study [26] } \\
\text { mentioned } \\
\text { above. }\end{array}$ & - As above & - As above & - As above & $\begin{array}{l}\text { At } 24 \text { months, the control } \\
\text { group was not significantly } \\
\text { better as compared to } \\
\text { baseline. } \\
\text { At } 24 \text { months, } 57 \% \text { of } \\
\text { patients had at least } 50 \% \\
\text { pain relief and } 23 \% \text { had } \\
\text { complete pain relief. } \\
\text { Results at } 6 \text { months FU is } \\
\text { stable as } 12 \text { and } 24 \text { months } \\
\text { FU in the majority of } \\
\text { patients. }\end{array}$ & $\begin{array}{l}\text { Interestingly, } \\
\text { though the } \\
\text { initial study } \\
\text { stated that the } \\
\text { control group } \\
\text { was lost to FU } \\
\text { after } 3 \text { months, } \\
\text { this study } \\
\text { managed to get } \\
\text { results from } \\
\text { them at both } 12 \\
\text { months and } 24 \\
\text { months. }\end{array}$ \\
\hline $\begin{array}{l}\text { Freed } \\
\text { man } \\
\text { et al. [30] }\end{array}$ & $\begin{array}{l}\text { Prospective. } 36 \\
\text { patients who are } \\
\text { active military } \\
\text { personnel. } \\
\text { Mean FU of } 29.7 \\
\text { months. }\end{array}$ & $\begin{array}{l}\text { •Failed } 6 \text { months } \\
\text { of non-operative } \\
\text { treatment of } \\
\text { chronic LBP } \\
\text { •Positive } \\
\text { provocative } \\
\text { discography } \\
\text { • MRI showing no } \\
\text { nerve compression, } \\
\text { tumour/ } \\
\text { infection or } \\
\text { osteoligamentous } \\
\text { trauma } \\
\text { - Absence of } \\
\text { prominent } \\
\text { radicular symptoms } \\
\text { and signs }\end{array}$ & $\begin{array}{c}\text { • Non-active duty } \\
\text { status } \\
\text { - Previous lumbar } \\
\text { fusion history } \\
\text { • Severe spinal } \\
\text { stenosis } \\
\text { - Spondylolisthesis, } \\
\text { inflammatory } \\
\text { arthritis or neoplastic } \\
\text { disease } \\
\text { • Predominant } \\
\text { radicular pain or } \\
\text { positive neurological } \\
\text { findings } \\
\text { - Medical or } \\
\text { metabolic condition } \\
\text { that would preclude } \\
\text { appropriate FU and } \\
\text { participation. }\end{array}$ & $\begin{array}{c}\text { IDET } \\
\text { protocol not } \\
\text { mentioned. } \\
\\
17 \text { patients } \\
\text { had } 1 \text { level } \\
\text { treated. } 14 \\
\text { patients } \\
\text { had } 2 \text { levels } \\
\text { treated. }\end{array}$ & $\begin{array}{c}5 \text { patients lost at }>6 \\
\text { months FU. } \\
47 \% \text { of } 36 \text { patients had } \\
>50 \% \text { reduction at } 6 \\
\text { months FU but only } 16 \% \text { at } \\
\text { final FU. } \\
52 \% \text { had a } 2 \text { point or } \\
\text { greater decrease in NRS. } \\
29 \% \text { stated they had } \\
\text { improved at final FU and } \\
\text { only } 16 \% \text { said they were } \\
\text { satisfied with IDET. }\end{array}$ & $\begin{array}{l}\text { Additional } 5 \\
\text { patients were } \\
\text { treated that was } \\
\text { not in statistical } \\
\text { analysis. } 3 \text { had } \\
\text { another IDET } \\
\text { procedure done } \\
\text { at another } \\
\text { setting at an } \\
\text { adjacent disc } \\
\text { after good } \\
\text { success from } \\
\text { first IDET. } 2 \text { had } \\
\text { a repeat IDET } \\
\text { done at the same } \\
\text { level due to poor } \\
\text { result. } \\
\\
5 \text { complications } \\
\text { (16\%): Foot } \\
\text { drop, increased } \\
\text { disc herniation, } \\
\text { decreased } \\
\text { sphincter tone } \\
\text { and faecal } \\
\text { incontinence } \\
\text { and increased } \\
\text { or new } \\
\text { nondermatomal } \\
\text { leg pain x } 2 \text {. }\end{array}$ \\
\hline
\end{tabular}




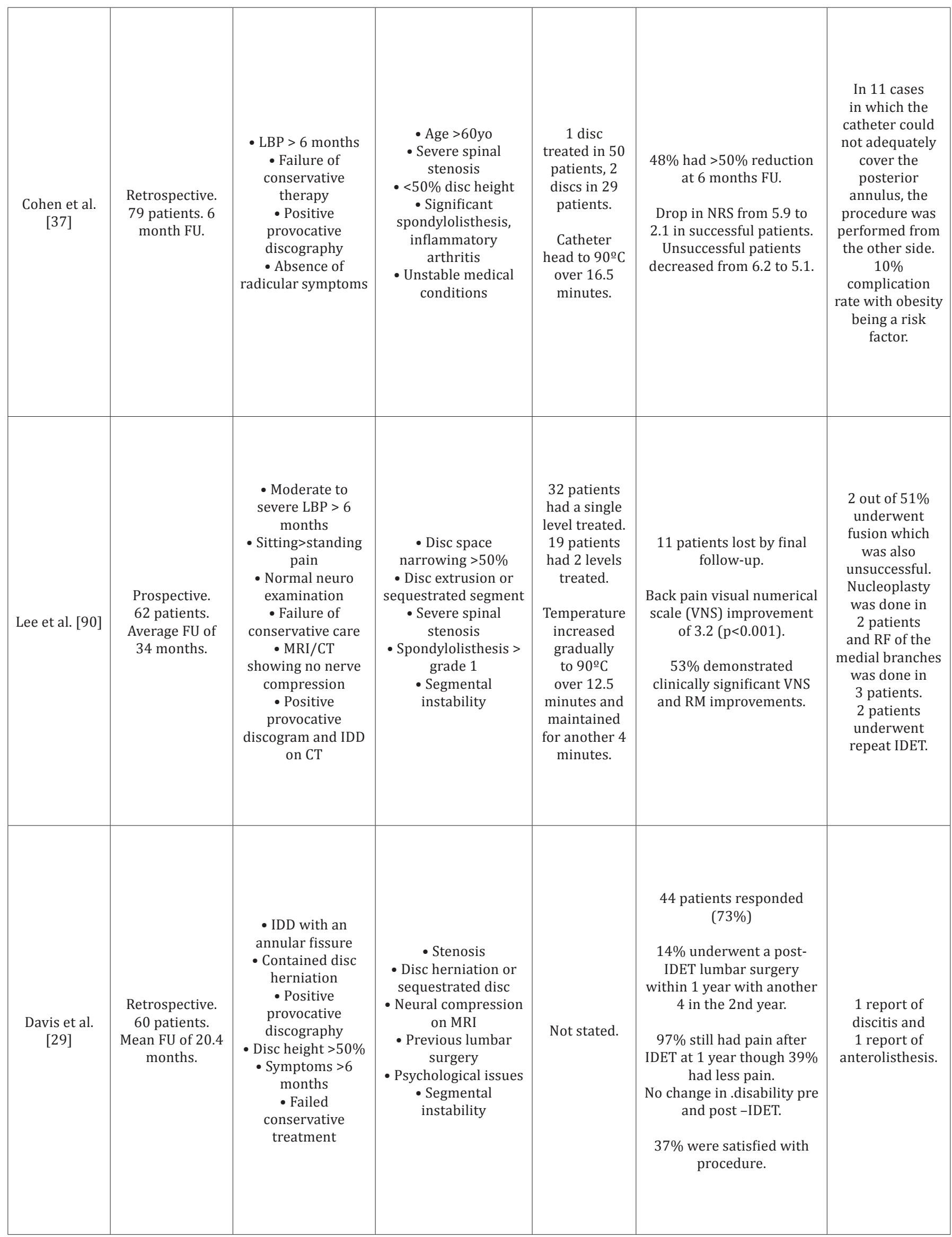




\begin{tabular}{|c|c|c|c|c|c|c|}
\hline $\begin{array}{c}\text { Pauza et al. } \\
\text { [32] }\end{array}$ & $\begin{array}{l}\text { RCT of IDET vs. } \\
\text { sham placebo. } 6 \\
\text { months FU. } \\
\text { 37 IDET, } 27 \\
\text { placebo }\end{array}$ & $\begin{array}{c}\text { • 18-65yo } \\
\text { • LBP > leg pain for } \\
>6 \text { months } \\
\text { - Failure to improve } \\
\text { after } 6 \text { weeks } \\
\text { of conservative } \\
\text { management } \\
\text { - LBP exacerbated } \\
\text { by sitting/standing } \\
\text { and relieved by } \\
\text { lying down } \\
\bullet<20 \text { on Beck } \\
\text { Depression scale } \\
\bullet \text { No surgical } \\
\text { intervention within } \\
\text { last } 3 \text { months } \\
\text { - } 20 \% \text { disc height } \\
\text { loss } \\
\text { - Positive } \\
\text { provocative } \\
\text { discography } \\
\text { and posterior } \\
\text { annular tear on CT } \\
\text { discogram. }\end{array}$ & $\begin{array}{c}\text { - Previous lumbar } \\
\text { surgery } \\
\text { - Abnormal } \\
\text { neurological exam } \\
\text { - Radicular pain } \\
\text { • Structural } \\
\text { deformities } \\
\text { - Vertebral canal } \\
\text { stenosis or scoliosis } \\
\text { - Herniations }>4 \mathrm{~mm} \\
\text { or sequestrated } \\
\text { herniations } \\
\text { - Concomitant } \\
\text { cervical or thoracic } \\
\text { pain }>2 \text { on VAS } \\
\text { - Uncontrolled } \\
\text { medical conditions } \\
\text { - Injury litigation } \\
\text { • Disability } \\
\text { remuneration }\end{array}$ & $\begin{array}{l}15 \text { patients } \\
\text { were treated } \\
\text { at } 2 \text { levels, } 22 \\
\text { at } 1 \text { level. } \\
\\
\text { Catheter } \\
\text { heated to } \\
90^{\circ} \text { C over } 13 \\
\text { minutes and } \\
\text { maintained } \\
\text { for another } 4 \\
\text { minutes. }\end{array}$ & $\begin{array}{c}56 \% \text { of IDET and } 38 \% \\
\text { of placebo had }>2 \text { points } \\
\text { improvement in VAS. Only } \\
40 \% \text { of patients with IDET } \\
\text { had }>50 \% \text { reduction in } \\
\text { pain vs. } 33 \% \text { in placebo. } \\
\text { Both groups had significant } \\
\text { improvements in pain } \\
\text { scores but the IDET group } \\
\text { had statistically greater } \\
\text { improvements. } \\
\text { Mean change in VAS is } 2.4 \text {. } \\
\text { IDET group had better } \\
\text { outcomes in ODI. } \\
\text { NNT for IDET for }>75 \% \\
\text { relief = 5. }\end{array}$ & $\begin{array}{c}\text { Jadad scoring = } 5 \\
\text { Per Protocol } \\
\text { analysis. } \\
\text { Moderate loss } \\
\text { to FU rate with } \\
\text { the results of } \\
86 \% \text { in IDET and } \\
89 \% \text { in placebo } \\
\text { analyzed. } \\
\text { Study initially } \\
\text { wanted to have } \\
40 \text { patients } \\
\text { in IDET and } \\
27 \text { patients in } \\
\text { placebo but } \\
\text { this was not } \\
\text { obtained. Power } \\
\text { dropped from } 80 \\
\text { to } 60 \% \text {. }\end{array}$ \\
\hline $\begin{array}{l}\text { Freeman et } \\
\text { al. [33] }\end{array}$ & $\begin{array}{c}\text { RCT. IDET vs. } \\
\text { Sham Placebo. } \\
57 \text { patients in } \\
\text { total. } 6 \text { months } \\
\text { FU. } \\
\text { 38 IDET and } 19 \\
\text { to placebo. }\end{array}$ & $\begin{array}{c}\bullet>18 y o \\
\text { - Single or } 2 \text { level } \\
\text { disease } \\
\text { - Degenerative } \\
\text { lumbar disc disease } \\
>3 \text { months } \\
\text { - Failure of } \\
\text { conservative } \\
\text { management of } 6 \\
\text { weeks } \\
\text { - Marked functional } \\
\text { limitation } \\
\text { - Sitting intolerance } \\
>\text { standing } \\
\text { - Predominantly } \\
\text { LBP rather than leg } \\
\text { pain } \\
\text { - MRI shows disc } \\
\text { disease } \\
\text { - No evidence of } \\
\text { nerve compression }\end{array}$ & $\begin{array}{c}\text { - Large herniation or } \\
\text { sequestrated disc } \\
\text { - >50 disc height loss } \\
\text { - Severely disrupted } \\
\text { disc } \\
\text { - Spinal stenosis } \\
\text { - >2 symptomatic } \\
\text { levels } \\
\text { - Previous lumbar } \\
\text { surgery } \\
\text { - Spondylolisthesis at } \\
\text { symptomatic level } \\
\text { - Psychological } \\
\text { conditions } \\
\text { - Medical conditions } \\
\text { that would affect } \\
\text { follow-up } \\
\text { - Current injury } \\
\text { litigation }\end{array}$ & $\begin{array}{l}\text { Temperature } \\
\text { increased } \\
\text { to } 90^{\circ} \mathrm{C} \\
\text { over } 12.5 \\
\text { minutes and } \\
\text { maintained } \\
\text { for } 4 \text { minutes. }\end{array}$ & $\begin{array}{c}\text { Successful outcome is } \\
\text { defined as no neurological } \\
\text { deficit, improvement of at } \\
\text { least } 7 \text { points in Low Back } \\
\text { Pain Outcome score and } \\
\text { improvement of } 1 \text { standard } \\
\text { deviation from mean in } \\
\text { SF-bodily pain and physical } \\
\text { functioning subscales at } 6 \\
\text { months. } \\
\text { No patient in either group } \\
\text { achieved a successful } \\
\text { outcome. } \\
\text { No difference between the } \\
\text { IDET and placebo group } \\
\text { in primary and secondary } \\
\text { outcomes. }\end{array}$ & $\begin{array}{l}\text { Jadad Scoring: } \\
4 \text { (method of } \\
\text { randomization } \\
\text { not stated) } \\
\text { Target sample } \\
\text { size was } 50 \text { IDET } \\
\text { and } 25 \text { Placebo } \\
\text { for } 80 \% \text { power. } \\
\text { Compared to } \\
\text { Pauza's study, } \\
\text { the patients } \\
\text { were more } \\
\text { disabled at } \\
\text { baseline. } \\
\\
\text { Pain scores not } \\
\text { an outcome } \\
\text { measure. } \\
\text { 50\% of patients } \\
\text { in both groups } \\
\text { on Worker's } \\
\text { Compensation }\end{array}$ \\
\hline $\begin{array}{c}\text { Maurer et al. } \\
\text { [91] }\end{array}$ & $\begin{array}{l}\text { Prospective. } \\
56 \text { patients. } \\
\text { Mean FU of } 20.5 \\
\text { months. }\end{array}$ & $\begin{array}{l}\bullet \text { LBP and impaired } \\
\text { function }>6 \\
\text { months } \\
\bullet<50 \% \text { height loss } \\
\bullet \text { Normal } \\
\text { neurological exam } \\
\bullet 1-3 \text { desiccated } \\
\text { disc on MRI } \\
\bullet \text { Positive } \\
\text { provocative } \\
\text { discography } \\
\bullet \text { Posterior } \\
\text { annulus tear on CT } \\
\text { discogram }\end{array}$ & $\begin{array}{c}\text { - Severe disc } \\
\text { degeneration } \\
\text { • Extruded or } \\
\text { sequestrated } \\
\text { herniation } \\
\text { - Previous lumbar } \\
\text { surgery } \\
\text { - Chronic lower limb } \\
\text { radiculopathy } \\
\text { - Spinal canal } \\
\text { stenosis }>30 \% \\
\text {-Spondylolisthesis }\end{array}$ & $\begin{array}{c}30 \text { patients } \\
\text { treated at } 1 \\
\text { level, } 26 \text { at } 2 \\
\text { levels } \\
\text { Standardized } \\
\text { heating } \\
\text { procedure } \\
\text { used until } \\
60-65^{\circ} \mathrm{C} \\
\text { detected } \\
\text { adjacent to } \\
\text { the coil. }\end{array}$ & $\begin{array}{c}16 \% \text { receiving worker's } \\
\text { compensation } \\
75 \% \text { treatment success. } \\
\text { VAS improved from } 6.1 \text { to } \\
2.4 \text { at final FU. } \\
\text { Sitting, standing and } \\
\text { walking tolerance all had } \\
\text { statistically significant } \\
\text { improvements. }\end{array}$ & $\begin{array}{c}\text { No complications } \\
\text { noted. }\end{array}$ \\
\hline
\end{tabular}




\begin{tabular}{|c|c|c|c|c|c|c|}
\hline $\begin{array}{c}\text { Nunley et al. } \\
\text { [92] }\end{array}$ & $\begin{array}{c}\text { Prospective. } \\
53 \text { patients } \\
\text { with worker's } \\
\text { compensation. } \\
12 \text { months FU. }\end{array}$ & $\begin{array}{c}\text { - LBP }>6 \text { months } \\
\text { • Failure of } \\
\text { conservative } \\
\text { management } \\
\text { • Exclusion of } \\
\text { radiculopathy, } \\
\text { pseudo- } \\
\text { radiculopathy, facet } \\
\text { disease } \\
\text { - Positive } \\
\text { provocative } \\
\text { discography }\end{array}$ & $\begin{array}{c}\text { - Prior spine surgery } \\
\text { - Abnormal } \\
\text { neurological exam } \\
\text { • Structural } \\
\text { deformities } \\
\text { - Spinal stenosis } \\
\text { - Loss of }>60 \% \text { disc } \\
\text { height }\end{array}$ & $\begin{array}{c}38 \% \text { had } 1 \\
\text { level treated, } \\
58 \% 2 \text { levels } \\
\text { and } 4 \% \\
\text { had } 3 \text { levels } \\
\text { treated. } \\
\\
\text { Temperature } \\
\text { raised to } \\
90-95^{\circ} \mathrm{C} \text { and } \\
\text { maintained } \\
\text { for } 5 \text { minutes. }\end{array}$ & $\begin{array}{l}\text { Significant reduction in } \\
\text { both VAS }(62.6 \%) \text { and } \\
\text { Oswestry scores }(69.3 \%) \\
\text { Significant increase in } \\
\text { economic productivity } \\
\text { post-IDET. }\end{array}$ & $\begin{array}{c}1 \text { complication } \\
\text { stated but not } \\
\text { elaborated. }\end{array}$ \\
\hline $\begin{array}{c}\text { Assietti et al. } \\
\text { [93] }\end{array}$ & $\begin{array}{l}\text { Prospective. } \\
50 \text { patients. } 24 \\
\text { months FU. }\end{array}$ & $\begin{array}{c}\bullet \text { LBP }>6 \text { months } \\
\bullet \text { Failed } \\
\text { conservative } \\
\text { treatment }>6 \text { weeks } \\
\bullet \text { Sufficient } \\
\text { symptom severity } \\
\text { and duration to } \\
\text { be candidates for } \\
\text { surgery } \\
\text { - Severe LBP } \\
\text { increased on hyper } \\
\text { flexion. } \\
\text { - Single level } \\
\text { disruption } \\
\bullet \text { Positive } \\
\text { provocative } \\
\text { discography } \\
\bullet>60 \% \text { disc height }\end{array}$ & $\begin{array}{c}\text { • Extruded or } \\
\text { sequestrated disc } \\
\text { - Previous lumbar } \\
\text { surgery at affected } \\
\text { level } \\
\text { - IDET performed } \\
\text { within last } 6 \text { months } \\
\text { • Nerve root } \\
\text { impingement } \\
\text { - Spinal stenosis } \\
\text { - Spondylolisthesis } \\
\text { • Cervical } \\
\text { degenerated discs } \\
\text { - Major psychological } \\
\text { impairment }\end{array}$ & $\begin{array}{l}\text { Temperature } \\
\text { increased } \\
\text { to } 90^{\circ} \mathrm{C} \\
\text { over } 12.5 \\
\text { minutes and } \\
\text { maintained } \\
\text { for } 4 \text { minutes. }\end{array}$ & $\begin{array}{l}78 \% \text { success rate at } 24 \\
\text { months. } \\
\text { Pain score improved } \\
\text { from } 7.6 \text { (baseline) to } 3.0 \\
\text { (12 months) and } 2.4 \text { ( } 24 \\
\text { months. } \\
\text { ODI improved from } 59.0 \\
\text { (baseline) to } 27.0 \text { (12 } \\
\text { months) and } 20.1 \text { ( } 24 \\
\text { months) } \\
\text { 9 patients still had severe } \\
\text { back pain at } 6 \text { months FU } \\
\text { and underwent surgery } \\
\text { (not factored into results } \\
\text { pain score and ODI) }\end{array}$ & $\begin{array}{c}\text { No } \\
\text { complications. } \\
\text { Patients who } \\
\text { have concordant } \\
\text { pain at low } \\
\text { pressures on } \\
\text { discography or } \\
\text { who had HIZ on } \\
\text { MRI had better } \\
\text { outcomes. }\end{array}$ \\
\hline
\end{tabular}

Complications stated in the literature includes cauda equina syndrome [30,34,35], increased disc herniation [30,36,37], vertebral osteonecrosis $[38,39]$, a broken catheter that migrated intradurally causing radiculopathy [40], nerve root injury [30,37] anterolisthesis and discitism [29]. Though severe complications can occur, the overall rate of complications is low. Based on multiple observational studies that show positive results, an RCT that showed fair results in selected patients and a RCT that showed a negative result, there is still clinical equipoise over this modality.

\section{DiscTRODE}

The discTRODE (Radionics, Burlington, MA, USA) is also based on a similar working principle as the IDET. First, a $17 \mathrm{G}$ curved and electrically insulated introducer needle is inserted into outer annulus from the contra-lateral side to the annular tear. Electrical impedance is checked and the needle is further advanced in the annulus until an impedance of $300-400 \Omega$ is obtained, which usually corresponds to that of a mid-annulus depth. The catheter is then inserted and it is navigated through the posterior annulus and upon contacting the lateral wall of the annulus, it travels anteriorly. As such, the electrode covers the posterolateral portion of the AF. The catheter is then heated to a maximum temperature of $65^{\circ} \mathrm{C}$ for 10 minutes.

The first published study on DiscTRODE was in 2005 by Finch et al. [41]. 31 patients underwent the procedure and another 15 who were refused funding became the control group. At 12-month follow-up, VAS scores had dropped 37\% in the treated group with a $3 \%$ increase in the control group. 9 out of 31 patients had $>50 \%$ drop in VAS scores. The ODI decreased significantly over the same period in treated patients. Interestingly, though VAS and ODI scores dropped in the treatment group, medication use did not decrease accordingly.

A comparative non-randomized study between IDET and DiscTRODE was published in 2005 by Kapural et al. [42]. 21 patients underwent the DiscTRODE procedure, in which the heating protocol consists of $55^{\circ} \mathrm{C}$ for 4 minutes, $60^{\circ} \mathrm{C}$ for 5 minutes then $65^{\circ} \mathrm{C}$ for 5 minutes. Another 28 patients underwent IDET and the patients in both groups were matched against each other. Patients in the DiscTRODE group had a decrease in VAS from 6.6 to 4.4 at 1-year follow-up but patients in the IDET group had a larger drop of 7.4 to 1.4. Though DiscTRODE had a significant drop, it was much smaller compared to IDET. $81 \%$ of patients in the IDET group had a $60 \%$ improvement in VAS as compared to $29 \%$ in the DiscTRODE group. As such, based on the results of this study, DiscTRODE is inferior to IDET for the treatment of discogenic LBP.

A well conducted (Jadad score $=5$ ) randomized, double blinded, placebo controlled trial was then conducted by Kvarstein et al. [43]. The placebo was a sham procedure in which the introducer needle and electrode were both inserted into the appropriate position but the RF current was not delivered. In the treatment group, incremental heating started at $50^{\circ} \mathrm{C}$ and this was increased by $5^{\circ} \mathrm{C}$ every 2 minutes. At $65^{\circ} \mathrm{C}$, the heating was maintained for 4 minutes. The authors intended to have 25 patients in each group but planned an interim analysis 
when 10 patients in each group had reached 6-month follow-up. Unfortunately, the interim analysis did not show any significant benefit to the patients who underwent DiscTRODE and so the study was discontinued. As such, this study did not attain the predetermined sample size and analysis of this study was based only on the 20 patients recruited. The VAS scores between the sham and treated group were not different. The treatment group had only a slight reduction of 1 compared to 0 in the sham group. There were more patients in the sham group who reported a 2 or greater decrease in VAS. In terms of complications, there is a case report of Complex Regional Pain Syndrome after the DiscTRODE procedure [44] but nothing else can be found in the literature.

As such, based on a well-conducted underpowered RCT which showed no significant difference between DiscTRODE and sham procedure, a comparative study that showed inferiority of DiscTRODE to IDET and a positive prospective study, the evidence is not supportive of DiscTRODE for the treatment of discogenic pain.

\section{Intradiscal Radiofrequency (RF)/ Percutaneous intradiscal radiofrequency thermocoagulation (PIRFT)}

Intradiscal RF first appeared in the literature in 1996. The hypothesis for its effectiveness in treating discogenic pain was that the heat produced would destroy the nerves in the AF. The intervertebral disc has poor internal circulation and the vertebral endplates act as insulators to trap the heat generated by the RF current within the disc [45]. The procedure consists of inserting a cannula with a $10 \mathrm{~mm}$ active tip into the centre of the NP. An RF electrode is then inserted and a lesion is made. The studies are presented in Table 2.

Table 2: Intradiscal Radiofrequency.

\begin{tabular}{|c|c|c|c|c|c|c|}
\hline $\begin{array}{c}\text { Author and } \\
\text { publication } \\
\text { year of } \\
\text { study }\end{array}$ & $\begin{array}{l}\text { Type of study, } \\
\text { number of } \\
\text { patients, } \\
\text { length of FU }\end{array}$ & $\begin{array}{l}\text { Inclusion } \\
\text { Criteria }\end{array}$ & Exclusion Criteria & $\begin{array}{l}\text { Intervention } \\
\text { performed }\end{array}$ & Results & Comments \\
\hline $\begin{array}{c}\text { Van Kleef et } \\
\text { al. [17] }\end{array}$ & $\begin{array}{l}\text { Prospective, } 39 \\
\text { patients. } \\
\text { Mean FU of } 16 \\
\text { months }\end{array}$ & $\begin{array}{c}\text { - Age } 25 \text { 60yo } \\
\text { • LBPwith or } \\
\text { without sciatica } \\
\text { for >12 months } \\
\text { - Failed } \\
\text { conservative } \\
\text { management } \\
\text { - Positive } \\
\text { anaesthetic } \\
\text { discography }\end{array}$ & $\begin{array}{l}\text { - Herniated disc with } \\
\text { nerve root compression } \\
\text { • Spinal stenosis } \\
\text { - Extensive multi-level } \\
\text { spondylosis } \\
\text { - Previous spinal fusion } \\
\text { - Psychological } \\
\text { problems } \\
\text { - Positive lumbar facet } \\
\text { blocks }\end{array}$ & $\begin{array}{c}1 \text { level } \\
\text { 20G C15 cannula } \\
\text { with } 10 \mathrm{~mm} \text { active } \\
\text { tip } \\
70^{\circ} \mathrm{C} \text { for } 90 \\
\text { seconds }\end{array}$ & $\begin{array}{c}54 \% \text { reported } \\
\text { adequate reduction of } \\
\text { pain at } 8 \text { weeks, } 41 \% \\
\text { at long-term FU } \\
\text { Better results seen } \\
\text { in patients without } \\
\text { previous disc surgery } \\
\text { Repeat MRI after } \\
\text { the procedure in } \\
10 \text { patients did } \\
\text { not reveal disc } \\
\text { degeneration } \\
\text { attributable to } \\
\text { procedure }\end{array}$ & $\begin{array}{l}\text { No complications } \\
\text { or adverse events }\end{array}$ \\
\hline $\begin{array}{l}\text { Barendse et } \\
\text { al. [14] }\end{array}$ & $\begin{array}{l}\text { RCT, control } \\
\text { group had } \\
\text { needle } \\
\text { inserted into } \\
\text { the disc but } \\
\text { no RF current } \\
\text { delivered. } \\
28 \text { patients. } \\
1 \text { year FU. }\end{array}$ & $\begin{array}{c}\bullet \text { Age 30-65yo } \\
\text { • LBP with or } \\
\text { without sciatica } \\
\text { for >12 months } \\
\text { • Failed } \\
\text { conservative } \\
\text { management } \\
\text { • Positive } \\
\text { anaesthetic } \\
\text { discography }\end{array}$ & $\begin{array}{c}\text { • Spinal stenosis } \\
\text { - Extensive multi-level } \\
\text { spondylosis } \\
\text { - Previous spinal fusion } \\
\text { - Psychological } \\
\text { problems } \\
\text { - Positive lumbar facet } \\
\text { blocks } \\
\text { - Pregnancy } \\
\text { - Coagulation } \\
\text { disturbances } \\
\text { - VAS score less than } 5 \\
\text { - Diabetes mellitus } \\
\text { - } 1 \text { pain syndrome }\end{array}$ & $\begin{array}{c}\text { Single level } \\
\text { 20G C15 cannula } \\
\text { with 10mm active } \\
\text { tip }\end{array}$ & $\begin{array}{l}\text { 2-point reduction } \\
\text { in VAS and }>50 \% \\
\text { reduction on global } \\
\text { perceived effect } \\
\text { considered a success } \\
\text { Only } 1 \text { out of } 13 \\
\text { patients in the } \\
\text { treatment group and } \\
2 \text { out of } 15 \text { patients } \\
\text { in the control group } \\
\text { had success at } 8 \\
\text { weeks. At } 1 \text { year, } \\
\text { only } 1 \text { patient in the } \\
\text { treatment group still } \\
\text { had success. } \\
\text { No complications }\end{array}$ & $\begin{array}{l}\text { Jadad scoring: } 5 \\
\text { Sample size } \\
\text { calculation } \\
\text { not mentioned } \\
\text { so unable to } \\
\text { determine if study } \\
\text { was adequately } \\
\text { powered. } \\
\text { This study showed } \\
\text { no difference } \\
\text { between control } \\
\text { or intradiscal RF } \\
\text { group. }\end{array}$ \\
\hline
\end{tabular}




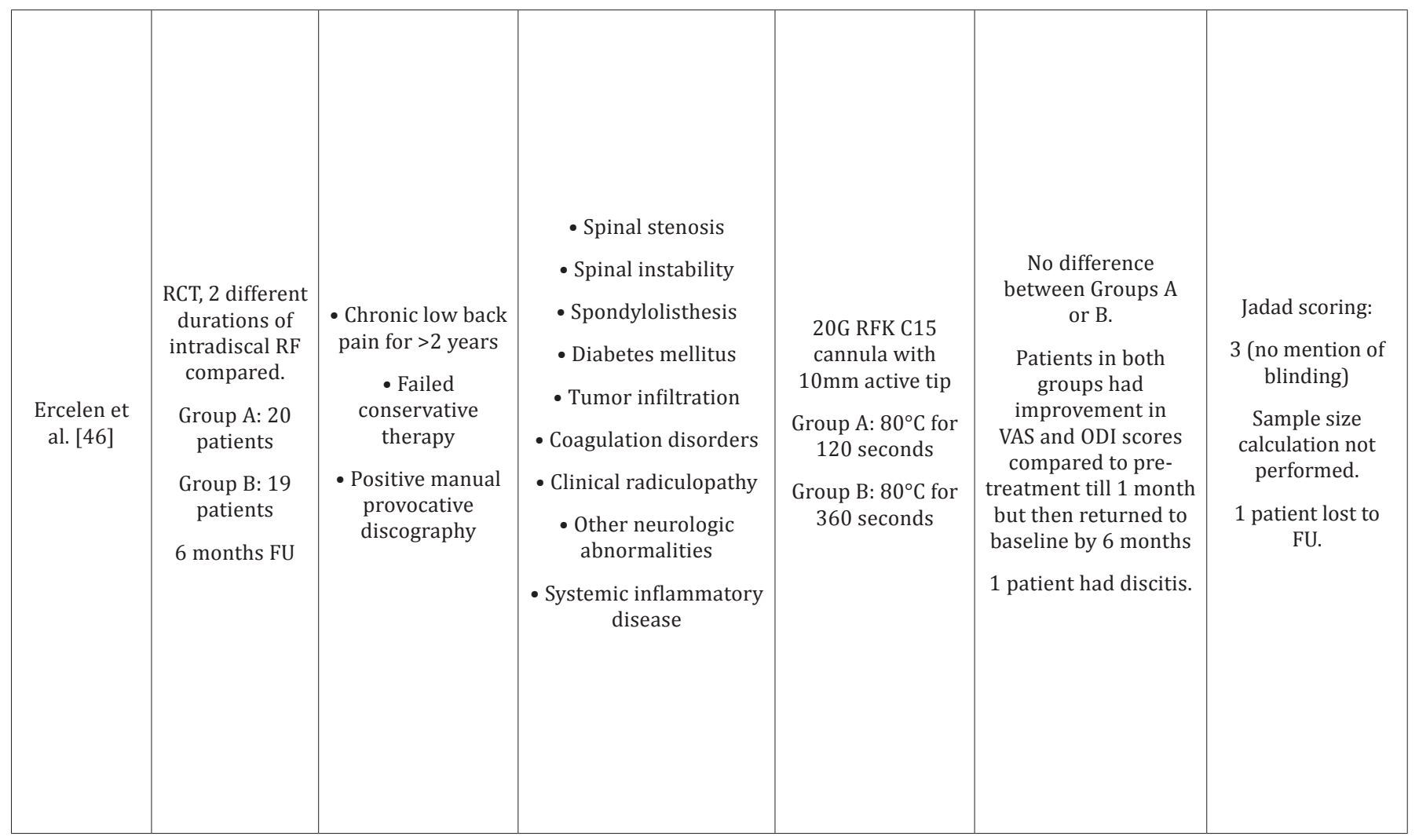

The first single cohort prospective observational trial was published by van Kleef et al. [17]. After positive anesthetic discography, the patients had RF of the intervertebral disc to achieve a temperature of $70^{\circ} \mathrm{C}$ for 90 seconds. This study showed positive results with $70 \%$ of patients having pain reduction at 8 weeks and $55 \%$ on longer follow up (mean of 16 months) if they have not had previous surgery on the affected disc. The results for patients who have had surgery on the affected intervertebral disc were worse with only $37 \%$ of patients having pain relief at 8 weeks and $27 \%$ on longer follow-up. A good quality RCT was then conducted based on the positive results from the previous prospective study [14]. Barendse et al. [14] randomized 28 patients with positive anaesthetic discography into a treatment group which used the same settings for RF as above, and a control group which had a needle inserted into the intervertebral disc but no RF applied. In contrast to the previous study, only 2 patients in the control group and 1 patient in the treatment group had a positive response at 8 weeks. By 1 year, only 1 patient in the treatment group still had a successful outcome. This RCT showed no difference between the treatment group and the control group.

Another group conducted a RCT of moderate quality in 2003. Ercelen et al. [46] randomized 39 patients into 2 groups, the first of which had RF delivered to obtain $80^{\circ} \mathrm{C}$ for 120 seconds and the second group had it maintained for 360 seconds. At 6-month follow-up there was no difference between the 2 groups. Both the groups had significant pain reduction up to 1-month post procedure but they returned to pre-treatment levels by 6 months. With regards to complications, there was 1 case of discitis reported in the trial by Ercelen et al. [46].

In summary, there are 2 RCTs which showed that intradiscal $\mathrm{RF}$ has no long-term utility in the treatment of discogenic pain. Both the RCTs did not show sample size calculation and so it is uncertain if the lack of efficacy of intra-discal RF is due to a lack of power in the trials or that it is truly ineffective. It is unlikely that any more trials would be conducted for this modality as results from both the RCTs were disappointing. In addition, IDET and biacuplasty delivers a targeted thermocoagulation of the posterior AF as compared to intradiscal RF which should theoretically produce better results. Based on current evidence, there is no role for intradiscal RF.

\section{Intradiscal Pulsed Radio Frequency (pRF)}

pRF has been gaining popularity in recent years and several studies has used it intradiscally for discogenic pain (Table 3 ). The highest temperature attained with $\mathrm{pRF}$ is limited to $42^{\circ} \mathrm{C}$ and so thermal destruction of the aberrant nociceptive nerves in the disc does not occur with pRF. The most likely pathway for the therapeutic effect is that the electric field generated induces changes in the nerves targeted and so generate a long term analgesic effect [47]. The technique of inserting the cannula is similar to that for provocative discography. An RF electrode is then inserted and the current delivered. Teixeira et al. [48] was the first to publish an article on the use of pRF intradiscally. There were significant decreases in NRS in the 8 patients in his study and at least a 4-point drop in NRS at 3 months. 
Table 3: Intradiscal Pulsed Radiofrequency (pRF).

\begin{tabular}{|c|c|c|c|c|c|c|}
\hline $\begin{array}{c}\text { Author and } \\
\text { publication } \\
\text { year of } \\
\text { study }\end{array}$ & $\begin{array}{l}\text { Type of } \\
\text { study, } \\
\text { number of } \\
\text { patients, } \\
\text { length of } \\
\text { follow-up }\end{array}$ & Inclusion Criteria & Exclusion Criteria & $\begin{array}{c}\text { Intervention } \\
\text { performed }\end{array}$ & Results & Comments \\
\hline $\begin{array}{l}\text { Teixeira et } \\
\text { al. [48] }\end{array}$ & $\begin{array}{l}\text { Prospective, } \\
8 \text { patients, } \\
\text { median FU of } \\
9 \text { months }\end{array}$ & $\begin{array}{c}\bullet \text { LBP > } 6 \text { months } \\
\text { - Normal neurological } \\
\text { exam } \\
\text { - Negative medial } \\
\text { branch block } \\
\text { - Single level discogenic } \\
\text { pain diagnosed by } \\
\text { manually controlled low } \\
\text { pressure discography }\end{array}$ & Not described & $\begin{array}{c}\text { 20G SMK } \\
\text { C15 cannula } \\
15 \mathrm{~mm} \text { active } \\
\text { tip } \\
2 \mathrm{~Hz} 20 \mathrm{~ms} \\
60 \mathrm{~V} \text { for } 20 \\
\text { minutes }\end{array}$ & $\begin{array}{c}\text { Significant fall } \\
\text { ( }<<0.0001) \text { in NRS in the } \\
\text { 1st week and this is also } \\
\text { seen by the } 3 \text { rd month } \\
(\mathrm{p}<0.0001) \\
\text { All patients had a fall of } \\
\text { at least } 4 \text { points in NRS } \\
\text { by } 3 \text { months. } \\
\text { Follow-up data of } 5 \\
\text { patients at a mean of } \\
12.8 \text { months showed } 4 \\
\text { were pain free, } 1 \text { has an } \\
\text { NRS of } 2 .\end{array}$ & $\begin{array}{l}\text { First study to use } \\
\text { pRF intradiscally. }\end{array}$ \\
\hline $\begin{array}{c}\text { Fukui et al. } \\
\text { [16] }\end{array}$ & $\begin{array}{l}\text { Prospective, } \\
16 \text { patients } \\
\text { in the IDET } \\
\text { group (Apr } \\
2003 \text { to } \\
\text { March 2009), } \\
15 \text { patients } \\
\text { in the } \\
\text { intradiscal } \\
\text { pRF group } \\
\text { (April 2009 } \\
\text { to March } \\
\text { 2011), } 6 \\
\text { months FU }\end{array}$ & $\begin{array}{c}\text { •LBP >6 months } \\
\text { • Failed conservative } \\
\text { therapy including } \\
\text { epidural steroid } \\
\text { • Normal neurological } \\
\text { exam } \\
\text { • Negative SLR } \\
\text { • MRI did not show } \\
\text { a nerve compressive } \\
\text { lesion } \\
\text { - Concordant pain at } \\
\text { low pressurization } \\
\text { during discography } \\
\text { - Positive discoblock } \\
\text { with 1ml of } 2 \% \\
\text { lignocaine }\end{array}$ & $\begin{array}{l}\text { - Disc sequestration } \\
\text { or extrusion } \\
\text { - Canal stenosis } \\
\text { - Psychological } \\
\text { issues } \\
\text { - Previous lumbar } \\
\text { surgery } \\
\text { - History of opioid } \\
\text { abuse } \\
\text { - Chronic lower limb } \\
\text { radiculopathy } \\
\text { - Systemic infection } \\
\text { or localized infection } \\
\text { over needle entry } \\
\text { points }\end{array}$ & $\begin{array}{c}\text { Diskit II } \\
\text { needle. } 20 \mathrm{G}, \\
20 \mathrm{~mm} \text { active } \\
\text { tip } \\
\\
5 \mathrm{~Hz} 5 \mathrm{~ms} 60 \mathrm{~V} \\
15 \mathrm{~min} \mathrm{max} \\
\text { temp } 40^{\circ} \mathrm{C}\end{array}$ & $\begin{array}{l}\text { IDET: NRS decreased } \\
\text { from } 7.5 \text { (pre) to } 4.6 \text { ( } 1 \\
\text { month) to } 1.7 \text { (6 months) } \\
\text { ( } \mathrm{p}<0.01 \text { ) } \\
\text { RMDQ scores: } 10.4 \text { (pre) } \\
\text { to } 8.9 \text { (1 month) to } 2.8 \text { (6 } \\
\text { month) (p<0.01) } \\
\text { pRF: NRS decreased } \\
\text { from } 7.2 \text { (pre) to } 3.4 \text { ( } 1 \\
\text { month) to } 2.5 \text { (6 month) } \\
\text { (p<0.01). RMDQ scores: } \\
10.8 \text { (pre) to } 3.5(1 \\
\text { month) to } 2.3(6 \text { month) } \\
\text { (p<0.01) } \\
\text { No complications }\end{array}$ & $\begin{array}{c}87.5 \% \text { of } \\
\text { IDET patients } \\
\text { complained of } \\
\text { flare-up pain after } \\
\text { procedure that } \\
\text { lasted 1-8 weeks. } \\
\text { Discoblock was } \\
\text { used as part of } \\
\text { diagnostic criteria. }\end{array}$ \\
\hline $\begin{array}{c}\text { Jung YJ et al. } \\
\text { [49] }\end{array}$ & $\begin{array}{c}\text { Prospective, } \\
26 \text { patients, } \\
12 \text { months } \\
\text { FU }\end{array}$ & $\begin{array}{c}\text { - LBP }>6 \text { months with } \\
\text { VAS }>4 \text { and ODI }>30 \% \\
\text { - Pain provoked on } \\
\text { prolonged sitting } \\
\text { - Normal neurological } \\
\text { examination } \\
\text { - Concordant pain by } \\
\text { low pressure automated } \\
\text { discography }\end{array}$ & $\begin{array}{c}50 \% \text { decrease in } \\
\text { height of disc } \\
\text { • Extruded or } \\
\text { sequestrated disc } \\
\text { - Previous back } \\
\text { surgery } \\
\text { - Chronic lower limb } \\
\text { radiculopathy } \\
\text { - Spinal canal } \\
\text { stenosis } \\
\text { - Instability } \\
\text { - Psychiatric disease }\end{array}$ & $\begin{array}{c}\text { SMK C15 } \\
\text { cannula, } 20 \mathrm{G} \\
15 \mathrm{~mm} \text { active } \\
\text { tip } \\
\\
2 \mathrm{~Hz}, 20 \mathrm{~ms} \\
60 \mathrm{~V} \text { for } 20 \\
\text { minutes }\end{array}$ & $\begin{array}{l}\text { VAS: } 6.4 \text { (pre) to } 4.1 \\
\text { (1 month) to } 4.4(12 \\
\text { months) (p<0.01) } \\
\text { ODI: } 47.3 \text { (pre) to } 33.7 \\
\text { (1 month) to } 36.7(12 \\
\text { months) }(\mathrm{p}<0.05) \\
35 \% \text { had }>50 \% \\
\text { reduction, } 7 \% \text { had } \\
\text { improvement of } 2 \text { in the } \\
\text { VAS but }<50 \%, 58 \% \text { no } \\
\text { improvement } \\
\text { Sitting tolerance: } 27.8 \\
\text { min(pre) to } 70.8(1 \\
\text { month) to } 71.5(12 \\
\text { months) } \\
\text { No complications }\end{array}$ & $\begin{array}{l}\text { pRF done within } \\
1 \text { week of } \\
\text { discography } \\
\text { Though drop } \\
\text { in VAS and ODI } \\
\text { were statistically } \\
\text { significant but } \\
\text { the absolute } \\
\text { improvements are } \\
\text { small. } \\
12 \text { patients had } 1 \\
\text { disc treated, } 12 \text { at } \\
2 \text { levels and } 2 \text { at } 3 \\
\text { levels. }\end{array}$ \\
\hline
\end{tabular}




\begin{tabular}{|c|c|c|c|c|c|c|}
\hline $\begin{array}{l}\text { Rohof et al. } \\
\text { [50] }\end{array}$ & $\begin{array}{l}\text { Prospective, } \\
76 \text { patients, } \\
\text { FU } 12 \\
\text { months }\end{array}$ & $\begin{array}{l}\bullet \text { LBP }>6 \text { months } \\
\text { refractory to } \\
\text { conservative } \\
\text { management } \\
\bullet>18 \text { years old } \\
\text { - Manual positive } \\
\text { provocative discography }\end{array}$ & $\begin{array}{l}\text { - Conditions like } \\
\text { tumour, infection, } \\
\text { fracture and nerve } \\
\text { compression }\end{array}$ & $\begin{array}{l}\text { Diskit needle. } \\
20 \mathrm{G} \text { with } 20 \\
\text { mm active tip } \\
2 \mathrm{~Hz} 10 \mathrm{~ms} \\
60 \mathrm{~V} \text { for } 15 \\
\text { minutes }\end{array}$ & $\begin{array}{c}3 \text { month FU: } 28.9 \% \\
\text { no effect, } 30 \% \text { had } \\
\text { improvement of at least } 2 \\
\text { NRS but }<50 \% \text { reduction, } \\
38 \% \text { had }>50 \% \\
\text { improvement, } 2.6 \% \text { had } \\
\text { surgery } \\
12 \text { month FU: } 26.3 \% \\
\text { no effect, } 14.4 \% \\
\text { improvement of } 2 \text { on } \\
\text { NRS but }<50 \% \text { reduction, } \\
56.5 \% \text { had }>50 \% \\
\text { reduction, } 2.6 \% \text { surgery } \\
\text { No complications }\end{array}$ & $\begin{array}{l}\text { pRF done } \\
\text { immediately after } \\
\text { discography. } \\
\text { After } 3 \text { months, } \\
\text { if results are } \\
\text { unsatisfactory, an } \\
\text { additional pain } \\
\text { procedure may } \\
\text { have been done. }\end{array}$ \\
\hline $\begin{array}{c}\text { Fukui et al. } \\
\text { [15] }\end{array}$ & $\begin{array}{c}\text { Prospective, } \\
23 \text { patients, } \\
\text { FU } 12 \\
\text { months }\end{array}$ & $\begin{array}{l}\text { • LBP >6 months } \\
\text { • Failed conservative } \\
\text { therapy including } \\
\text { epidural steroid } \\
\text { • Normal neurological } \\
\text { exam } \\
\text { • Negative SLR } \\
\text { - MRI did not show } \\
\text { a nerve compressive } \\
\text { lesion } \\
\text { - Concordant pain at } \\
\text { low pressurization } \\
\text { during discography + } \\
\text { positive discoblock with } \\
\text { 1ml of } 2 \% \text { lignocaine }\end{array}$ & $\begin{array}{l}\text { - Disc sequestration } \\
\text { or extrusion } \\
\text { - Canal stenosis } \\
\text { - Psychological } \\
\text { issues } \\
\text { - Previous lumbar } \\
\text { surgery } \\
\text { - History of opioid } \\
\text { abuse } \\
\text { - Chronic lower limb } \\
\text { radiculopathy } \\
\text { - Systemic infection } \\
\text { or localized infection } \\
\text { over needle entry } \\
\text { points }\end{array}$ & $\begin{array}{c}\text { Diskit II } \\
\text { needle. } 20 \mathrm{G}, \\
20 \mathrm{~mm} \text { active } \\
\text { tip } \\
5 \mathrm{~Hz} 5 \mathrm{~ms} 60 \mathrm{~V} \\
15 \mathrm{~min}, \mathrm{max} \\
\text { temp } 40^{\circ} \mathrm{C}\end{array}$ & $\begin{array}{c}\text { NRS dropped from } 7.47 \\
\text { down to } 3.47 \text { at } 1 \text { month } \\
\text { FU and sustained at } 3.13 \\
\text { at } 12 \text { month } F U(p<0.01) \\
\text { Rolland-Morris Disability } \\
\text { Questionnaire (RMDQ) } \\
\text { scores improved from } \\
11.4 \text { to } 5 \text { at } 1 \text { month } \\
\text { and } 2.90 \text { at } 12 \text { months } \\
\text { ( } \mathrm{p}<0.01 \text { ) } \\
4 \text { out of } 23 \text { had no } \\
\text { improvements. } 4 \text { out of } \\
23 \text { had a good outcome. } \\
\text { No complications } \\
\text { reported }\end{array}$ & $\begin{array}{l}\text { One of the few } \\
\text { studies that } \\
\text { used discoblock } \\
\text { in addition to } \\
\text { provocative } \\
\text { discography for } \\
\text { inclusion criteria } \\
3 \text { patients had } 2 \\
\text { discs treated } \\
\text { Only } 4 \text { out of } \\
23 \text { had a pain } \\
\text { reduction }>50 \% \text { at } \\
12 \text { months }\end{array}$ \\
\hline
\end{tabular}

Jung YJ et al. [49] then used intradiscal pRF in 26 patients [49]. More than half the patients had multiple levels treated. There were significant but small drops in VAS and ODI at 12-month follow-up. Only $35 \%$ of the patients had a reduction of $>50 \%$ in VAS at 12 months though. A relatively large prospective study of 76 patients was done by Rohof [50]. At the 3-month follow-up after intradiscal pRF, patients whose pain reduction was $<50 \%$ may have additional diagnostic and therapeutic interventions like $\mathrm{pRF}$ of the dorsal root ganglion or a RF ablation of the medial branches of the spinal nerves. At the 12-month follow-up, 56.5\% had a reduction of $>50 \%$ in NRS and this includes the group that just had intradiscal pRF alone and those in whom multiple procedures had been done. For the patients who only had intradiscal pRF, only $30 \%$ had a successful outcome at 1 year.

A comparative study of IDET against intradiscal pRF was then done by Fukui et al. [16]. The first group of patients underwent IDET from 2003 to 2009, then the 2nd group of patients underwent intradiscal pRF from 2009 to 2011. The inclusion and exclusion criteria for the 2 groups were the same. This study showed that pRF was comparable to IDET with significant decreases in NRS and in the Roland-Morris Disability Questionnaires. The same group of authors then performed intradiscal pRF for a prospective study of 23 patients [15]. $82.6 \%$ had at least a drop of 2 in the NRS, with $65.2 \%$ having $>50 \%$ reduction at 12 -month follow-up.
In summary, there is limited evidence for the efficacy of intradiscal pRF. Only prospective observational studies have been done and the results differ substantially between studies. More studies are needed and at the current time intradiscal pRF cannot be routinely recommended.

\section{Rami Communicans Radiofrequency Ablation}

There has only been 1 study published for this technique and the aim of the technique is to disrupt the nociceptive input from the AF by creating a thermal lesion in the rami communicans. In 2004, Oh et al. [51] published a RCT (Jadad score = 2) comparing radiofrequency ablation of the rami communicans above and below to the pathological disc versus a lignocaine $2 \%$ infiltration. No blinding or method of randomization was mentioned in the article. The study group consisted of patients who had a poor outcome following IDET at a single disc after a positive provocative discography. A diagnostic block of the rami communicans is first performed. If pain decreases $>50 \%$, the $\mathrm{RF}$ procedure is repeated one day later. A curved needle with a $10 \mathrm{~mm}$ active tip is directed to the inferior third of the vertebral body. The needle should then lie in the postero-lateral $1 / 3$ of the vertebral body where the rami communicans runs. The control group receives 2 millilitres of $1 \%$ lignocaine but the treatment group gets $\mathrm{RF}$ thermocoagulation at $65^{\circ} \mathrm{C}$ for 60 seconds. 26 patients were in the treatment group and 23 patients in the control group. All patients completed 4 months of follow-up. 
The patients in the treatment group had significantly better improvements in the VAS and SF-36 scores. Mean VAS dropped from 7.1 to 3.8 in the treatment group.

Though the results from this RCT were positive, it was not well conducted and the inclusion criteria of patients who failed IDET are not generalizable to all patients with discogenic pain.

\section{L2 Selective Blockade and Radiofrequency Ablation}

Another possible route of nociceptive transmission of a painful intervertebral disc back to the spinal cord is via the lumbar sympathetic chain. It is postulated that nociceptive fibers from the $\mathrm{AF}$ of the lower lumbar intervertebral discs run through the rami communicans to the lumbar sympathetic chain. It then ascends the sympathetic chain, travels via the $\mathrm{L} 2 \mathrm{rami}$ communicans which then joins the ventral root of the L2 spinal nerve before reaching the spinal cord. Nakamura et al. [52] were the first group to investigate this pathway in 1996. 33 patients with LBP of at least 1 month and diagnosed with discogenic pain based only on physical examination, plain radiographs and MRI had a unilateral L2 nerve block with $1.5 \mathrm{ml}$ of $1.5 \%$ lignocaine. After 15 minutes, VAS scores (max of 20 points) and pain provocation were assessed. 26 patients had complete relief of ipsilateral pain and the remaining 7 had some relief. Mean VAS scores dropped from 10 to 1.7. The average duration of pain relief was 20.7 days.

Simopoulos et al. [53] then reported on a case series of 5 patients who underwent RF of the $\mathrm{L} 2$ rami communicans with good results. Patients had to have both a positive provocative discography and greater than $50 \%$ pain relief from diagnostic L2 rami communicans block to be considered for a RF treatment. This consisted of reaching a temperature of $80^{\circ} \mathrm{C}$ for one minute. There was improvement in the VAS scores, sitting tolerance and medication use. However, the pain relief only lasted for about 4 months following which the procedure had to be repeated to maintain the pain relief.

A negative prospective cohort study was then published by Richardson et al. [54]. Following positive manual provocative discography, 12 patients underwent bilateral L1 and L2 dorsal root ganglion (DRG) blocks using methylprednisolone $80 \mathrm{mg}$, clonidine $75 \mathrm{mcg}$ and $4 \mathrm{ml}$ of $0.5 \%$ bupivacaine in total. After 1 month, there were no differences in the pain scores and pain interference scores regarding daily activities pre- and postprocedure. The study was thus terminated. No complications were reported in any of the above studies. Conflicting results are seen in the studies on L2 nerve blockade and the numbers of patients are small in each study. It is uncertain if there is any utility in treating discogenic LBP with a L2 nerve root intervention. It is likely that the sympathetic chain is not the main route for the transmission of discogenic pain and that the traditional route via the cauda equina contains most of the nociceptive pathways. As such, there is no role for it in routine practice currently.

\section{Nucleoplasty}

The Spine Wand (Arthrocare Inc., Sunnyvale, CA, USA) utilizes coblation technology to decrease intradiscal pressure by removing a small amount of volume from the NP [55]. The coblation is meant to result in a decrease of about 1 millilitre of NP volume and thus causing a subsequent large fall in intradiscal pressure. Though it was initially used for radicular pain secondary to a herniated disc, it was also utilized in patients with discogenic LBP.

Only observational studies are found for the use of nucleoplasty in discogenic LBP (Table 4). Sharps et al. [55] first published this in 2002 where they had positive results up to 1 year in duration. Singh et al then published 3 prospective studies where all showed positive results with about $50 \%$ of patients obtaining greater than $50 \%$ pain relief at 1 year [56-58]. Reddy et al. [59] published a retrospective analysis of 49 patients with a mix of axial and radicular pain. The criteria for inclusion for axial back pain seemed to suggest that a positive provocative discography is not a requirement. As such, this study was not included in the Table. Similarly, the study by Masala et al. [60] had similar problems in their study and was not included in the table. Both these studies though had positive results. Another study by Kumar et al. [61] had positive results but concordant pain during discography was not an inclusion criteria though it was performed prior to nucleoplasty. They found that concordant pain had no predictive effect on the success of the procedure.

Table 4: Nucleoplasty.

\begin{tabular}{|c|c|c|c|c|c|c|}
\hline $\begin{array}{l}\text { Author and } \\
\text { publication } \\
\text { year of } \\
\text { study }\end{array}$ & $\begin{array}{c}\text { Type of study, } \\
\text { number of } \\
\text { patients. Length } \\
\text { of FU. }\end{array}$ & Inclusion Criteria & Exclusion Criteria & $\begin{array}{l}\text { Intervention } \\
\text { Performed }\end{array}$ & Results & Comments \\
\hline $\begin{array}{c}\text { Sharps et al. } \\
\text { [55] }\end{array}$ & $\begin{array}{l}\text { Prospective, } 49 \\
\text { patients with } 1 \\
\text { year FU }\end{array}$ & $\begin{array}{l}\text { - LBP with/without } \\
\text { radicular pain } \\
\text { - Failure of } 6 \text { weeks } \\
\text { of conservative } \\
\text { treatment + epidural } \\
\text { steroid injections } \\
\text { - Positive provocative } \\
\text { discography only } \\
\text { in patients without } \\
\text { radicular pain }\end{array}$ & $\begin{array}{c}\text { - Sequestrated } \\
\text { herniation } \\
\text { - Herniation }>1 / 3 \\
\text { spinal canal } \\
\text { - Spinal stenosis } \\
\text { - Presence of } \\
\text { progressive neurological } \\
\text { deficits } \\
\text { - Tumour, infection, } \\
\text { spinal fracture }\end{array}$ & $\begin{array}{c}17 \mathrm{G} \text { introducer } \\
\text { needle, } 6 \text { channels } \\
\text { created with Spine } \\
\text { Wand }\end{array}$ & $\begin{array}{l}\text { VAS scores } \\
\text { dropped from } \\
7.9 \text { (pre-) to } \\
3.6 \text { ( } 1 \text { month), } \\
3.1 \text { ( } 3 \text { months), } \\
3.2 \text { (6 months) } \\
\text { and } 4.3(12 \\
\text { months) } \\
79 \% \text { success } \\
\text { rate }\end{array}$ & $\begin{array}{c}1 \text { patient lost to } \\
\text { FU and only } 13 \\
\text { patients have } 12 \\
\text { month FU data. } \\
\text { No complications } \\
\text { Provocative } \\
\text { discography not } \\
\text { done in patients } \\
\text { with LBP and } \\
\text { radicular pain. }\end{array}$ \\
\hline
\end{tabular}




\begin{tabular}{|c|c|c|c|c|c|c|}
\hline $\begin{array}{l}\text { Singh et al. } \\
\text { [58] }\end{array}$ & $\begin{array}{c}\text { Prospective, } 67 \\
\text { patients with } 12 \\
\text { months FU }\end{array}$ & $\begin{array}{c}\text { - Contained disc } \\
\text { herniation with axial } \\
\pm \text { leg pain }>3 \text { months } \\
\text { • No neurological } \\
\text { deficit } \\
\text { • Failure of } \\
\text { conservative } \\
\text { management and } \\
\text { injection therapies } \\
\text { Positive provocative } \\
\text { discography }\end{array}$ & $\begin{array}{c}\text { • Litigation } \\
\text { • Heavy opioid usage } \\
\text { • Uncontrolled } \\
\text { psychological disorders } \\
\text { - Sequestrated disc } \\
\text { - Herniation }>1 / 3 \text { spinal } \\
\text { canal } \\
\text { • Infection } \\
\text { - Spinal instability } \\
\text { - Spinal stenosis }\end{array}$ & As above & $\begin{array}{c}56 \% \text { of } \\
\text { patients } \\
\text { reported }>50 \% \\
\text { pain relief at } \\
12 \text { months } \\
59 \% \text { of } \\
\text { patients had >2 } \\
\text { point reduction } \\
\text { in VAS at } 12 \\
\text { months. } \\
\text { Improvement } \\
\text { in sitting, } \\
\text { standing } \\
\text { and walking } \\
\text { tolerances. }\end{array}$ & $\begin{array}{c}\text { No data available } \\
\text { for } 20 \text { patients at } \\
12 \text { month FU as } \\
\text { not contactable, } \\
\text { in addition to } \\
6 \text { patients lost } \\
\text { to FU. } \\
\text { No complications }\end{array}$ \\
\hline $\begin{array}{c}\text { Singh et al. } \\
{[57]}\end{array}$ & $\begin{array}{l}\text { Prospective, } 80 \\
\text { patients with } 1 \\
\text { year FU. }\end{array}$ & As above & As above & As above & $\begin{array}{l}75 \% \text { had } \\
\text { decrease in } \\
\text { numeric pain } \\
\text { scores at } 12 \\
\text { months with } \\
\text { a statistically } \\
\text { significant } \\
\text { reduction of } \\
2.43 . \\
54 \% \text { of } \\
\text { patients had } \\
>50 \% \text { pain } \\
\text { relief. }\end{array}$ & $\begin{array}{l}11 \text { patients' data } \\
\text { not included at } \\
12 \text { months. } \\
\text { No complications }\end{array}$ \\
\hline $\begin{array}{c}\text { Singh et al. } \\
{[56]}\end{array}$ & $\begin{array}{l}\text { Prospective, } 47 \\
\text { patients with } 1 \\
\text { year FU. }\end{array}$ & $\begin{array}{c}\text { - LBP with failure of } \\
\text { conservative therapy } \\
>3 \text { months } \\
\text { - Positive provocative } \\
\text { discography } \\
\text { - No neurological } \\
\text { deficit } \\
\text { - Average pain score } \\
\text { of at least } 5\end{array}$ & As above & As above & $\begin{array}{l}53 \% \text { had }>50 \% \\
\text { pain relief at } \\
12 \text { months. } \\
\text { Improvements } \\
\text { in the ability } \\
\text { to sit, stand } \\
\text { and walk at } 12 \\
\text { months. }\end{array}$ & $\begin{array}{c}\text { Data for } 37 \\
\text { patients at } 1 \text { year } \\
\text { FU. } \\
\text { No complications }\end{array}$ \\
\hline $\begin{array}{c}\text { Yakovlev et } \\
\text { al. [94] }\end{array}$ & $\begin{array}{c}\text { Retrospective, } 22 \\
\text { patients with } 1 \\
\text { year FU }\end{array}$ & $\begin{array}{l}\text { - Axial/radicular pain } \\
>6 \text { months } \\
\text { - Failed conservative } \\
\text { management } \\
\text { - }<50 \% \text { disc height } \\
\text { loss } \\
\text { - No neurological } \\
\text { deficit } \\
\text { - Positive provocative } \\
\text { discography } \\
\text { - Contained disc } \\
\text { protrusion on MRI }\end{array}$ & $\begin{array}{c}\bullet \text { Infection } \\
\text { - Spinal tumour/facture } \\
\text { •> } 2 \text { symptomatic levels } \\
\text { • Previous surgery at } \\
\text { affected level } \\
\text { - Psychological } \\
\text { disorders }\end{array}$ & As above & $\begin{array}{l}68.2 \% \text { of } \\
\text { patients had } \\
>50 \% \text { pain } \\
\text { relief at } 12 \\
\text { months. } \\
\text { Mean decrease } \\
\text { of } 3.98 \text { points } \\
\text { in VAS scores } \\
\text { at } 12 \text { months } \\
72.7 \% \text { of } \\
\text { patients had } \\
>50 \% \text { daily } \\
\text { opioid usage } \\
\text { reduction at } 12 \\
\text { months } \\
\text { Significant } \\
\text { improvement } \\
\text { in functional } \\
\text { status at } 12 \\
\text { months }\end{array}$ & \\
\hline
\end{tabular}




\begin{tabular}{|c|c|c|c|c|c|c|}
\hline $\begin{array}{c}\text { Zhu et al. } \\
\text { [95] }\end{array}$ & $\begin{array}{c}\text { Retrospective, } 42 \\
\text { patients with } 2 \\
\text { year FU }\end{array}$ & $\begin{array}{l}\text { - Back pain } \pm \text { leg pain } \\
\text { - Failure of } \\
\text { conservative therapy } \\
\text { for } 6 \text { months } \\
\text { - }>50 \% \text { disc height } \\
\text { - Positive provocative } \\
\text { discography } \\
\text { - Contained disc } \\
\text { protrusion on MRI }\end{array}$ & $\begin{array}{c}\text { - Spinal stenosis } \\
\text { - Disc protrusion }>1 / 3 \\
\text { spinal canal } \\
\text { - Previous surgery } \\
\text { - Severe neurological } \\
\text { deficits } \\
\text { - Spinal tumour } \\
\text { - Infections }\end{array}$ & $\begin{array}{l}\text { As above. } \\
\text { In addition, } \\
\text { patients with } \\
\text { radicular } \\
\text { symptoms also } \\
\text { received a nerve } \\
\text { root injection of } \\
\text { betamethasone } \\
\text { and lidocaine }\end{array}$ & $\begin{array}{l}\text { VAS scores } \\
\text { for back pain } \\
\text { improved from } \\
7.7 \text { (pre-) to } \\
4.2 \text { ( } 2 \text { year FU) } \\
\text { (p<0.05) } \\
\text { VAS scores also } \\
\text { significantly } \\
\text { improved } \\
\text { for leg pain } \\
\text { though not for } \\
\text { numbness at } 2 \\
\text { year FU. } \\
\text { ODI dropped } \\
\text { form } 68.2 \\
\text { (pre-) to } 39.4 \\
\text { (2 year) }\end{array}$ & $\begin{array}{c}\text { Method of } \\
\text { discography did } \\
\text { not mention } \\
\text { negative control } \\
\text { discs } \\
\text { Patients with } \\
\text { predominantly } \\
\text { radicular pain } \\
\text { included. }\end{array}$ \\
\hline
\end{tabular}

Lastly, He et al. [62] published an interesting study in which they modified the technique of nucleoplasty and named it coblation annuloplasty. Instead of creating channels in the $\mathrm{NP}$, they purposely left the introducer needle at the edge of the outer annulus, and created 6 channels in the annulus instead. The selection criteria were good as only patients with discogenic LBP confirmed by provocative discography was included. In 17 patients, the mean VAS scores dropped from 6.5 to 3.2 at 6-month follow-up. In addition, 58.8\% of patients had greater than $50 \%$ pain relief.

The complications of nucleoplasty have been presented in another article [63] and it includes increased back pain, increased radicular pain, new onset transient lower limb neurological symptoms and epidural fibrosis. No complications were reported in the articles for discogenic pain. In summary, based only on observational studies in which some did not diagnose discogenic pain per IASP criteria before the procedure, nucleoplasty showed a consistently positive result. Based on the current literature, it is not possible to recommend this technique for routine clinical practice.

\section{Intradiscal Biacuplasty}

Intradiscal biacuplasty is essentially a cooled radiofrequency ablation of the posterior annulus. Two $17 \mathrm{G}$ introducers are inserted into the posterior annulus on both sides of the disc using fluoroscopic guidance. The electrodes, which are 18G in size with a $6 \mathrm{~mm}$ active tip, are then inserted through the introducers and these electrodes are cooled internally using circulating water. A bipolar current is then created between the 2 electrodes, thus creating a strip lesion between and around the electrodes, ablating the posterior and posterolateral annulus. The aim of biacuplasty is to destroy the abnormal nociceptors that are responsible for discogenic pain in the posterior aspect of the disc. A porcine study [64] and a cadaveric study [65] have shown that there is minimal thermal damage to the anterior disc or posterior longitudinal ligament.

2 prospective cohort studies and 1 RCT with a follow-up report at 1 year is found. Biacuplasty was first described in a case report by Kapural et al. [66]. The main author then enrolled 15 patients into a pilot study with a 6-month follow-up [67] with positive results. Another group then conducted a prospective study in 2011, again with 15 patients and 6 months follow-up, and improvements in the VAS and ODI were seen [68].

The only RCT on biacuplasty was done by Kapural et al. [69]. In this double blinded sham-controlled study consisting of 32 patients in each group with a follow-up of 6 months, positive results were seen in the treatment group in terms of statistically significant improvements in SF-36, NRS and ODI scores with no complications reported. However, 9 patients were lost to follow-up and the results stated were from a per protocol analysis. The same authors recently published a followup study to the RCT mentioned above [70]. The patients who underwent the treatment had follow-up to 1 year and the sham patients who elected to cross over to the treatment arm had follow-up to 6 months. Sustained improvements were seen at 12 months in the NRS and SF-36 scores but the improvement in ODI score became insignificant. For the cross-over patients, significant improvement in the SF-36 score was obtained but the improvements in NRS, ODI and opioid usage did not attain statistical importance. Similar to the criticism of the RCT, there was a high drop-out rate and a per-protocol analysis was used.

In summary, there is 1 RCT of moderate quality and 2 prospective studies that show positive results for intradiscal biacuplasty. No complications have been reported that is directly related to this procedure. There is certainly a need for more studies to be done on this promising procedure. There is some evidence that this modality may be useful for the treatment of discogenic pain.

\section{Methylene Blue (MB)}

The latest addition to the treatment of discogenic LBP is intradiscal MB. The postulated mechanism of action is that $\mathrm{MB}$ is neurolytic and it denervates the small nociceptive fibers that grow into a degenerated disc's annulus fibrosis [71,72]. MB is also a direct inhibitor of nitric oxide which is involved in the inflammatory process in the intervertebral disc $[73,74]$. 
5 studies have been published on it with the first being reported in 2005. In this prospective study [72] with a follow up of 18 months, Peng et al had very good results with intradiscal MB in 24 patients. The authors then went on to perform a well conducted multi-centre placebo controlled RCT [71] (Jadad score $=5$ ) in which similarly impressive results were replicated. Patients were followed for 24 months and large decreases in NRS and ODI were seen. These improvements were seen by 6 months and sustained up to 24 months.

Unfortunately, these results were not seen when other authors utilized MB in their own centers. Gupta et al. [75] had a small retrospective case series of 8 patients in which only 1 patient has 100\% relief at 6 months. 3 patients had relief for shorter durations of between 2 weeks to 5 months. The other 4 had no pain relief at all. Kim et al. [76] conducted a prospective study in 20 patients with a follow-up of 12 months. At 3 months' post-procedure, $55 \%$ had an improvement but this reduced to $25 \%$ at 12 months. The difference in this study as compared to the previously mentioned ones is that there was a 1 week lapse between PD and MB injection, and that a significant number of their patients ( $75 \%$ ) had treatment at 2 or more levels. There is a possibility that the patients in this study had more severe disease as compared to the other studies and as such their patients could not attain the same results as in Peng's study. The most recent study published was by Kallewaard et al. [77] as a pilot study to assess the efficacy of MB, and if it was effective to carry on and conduct a larger placebo controlled RCT. In their study, they defined success as a 30\% decrease in pain at 6 months which 6 out of 15 patients (40\%) managed to achieve.

In addition to questions over its overall efficacy, it is a relatively recent development of intradiscal therapy and so it is unknown if there is any utility or harm in repeating intradiscal MB injection in situations in which it provided short term pain relief.

In summary, there is a well-conducted RCT that showed very good results for intradiscal MB therapy but conflicting results were then shown in the other trials. There is some evidence that it may be efficacious but more studies will be needed to confirm this.

\section{Other Therapies}

A recent article describes a new navigable catheter, L'DISQ (U\&I Co. Ltd., Uijeongbu, Korea) that uses coblation technology to ablate the torn annulus. L'DISQ allows coblation to be performed directly to the annular tear as the catheter is navigable so it should theoretically be more effective. In this pilot study of 20 patients, which was conducted by the inventor of the device, 11 had greater than $50 \%$ pain reduction at 48-week follow-up [78]. More studies are needed to properly assess this modality.

Several articles have already been published utilizing percutaneous lumbar disc decompression (PLDD) for lumbar radicular pain but the literature of its effectiveness on discogenic
LBP is scanty. A prospective study was published in 2011 [79] which described its usage in discogenic pain. 11 patients with LBP secondary to a single level disease that had a selective anaesthetic blockade of $1 \mathrm{ml}$ of $1 \%$ lidocaine were included. At a follow-up of 2 years, there were significant improvements in ODI and VAS scores. 1 patient developed a discitis that needed surgery. The other study on the use of PLDD for discogenic pain was a retrospective report in which patients were included either based on clinical findings or a discography [80]. 32 patients responded to a telephone interview in which 28 had a good or fair response. More studies will be needed before this modality can be considered a viable treatment for discogenic LBP.

There are 2 articles that have been published investigating the efficacy of using etanercept, a TNF- $\alpha$ inhibitor, intradiscally. The first study was a double blind, placebo controlled, dose response RCT (Jadad score $=5$ ) in which intradiscal saline was compared against a range of etanercept doses with the maximum being $1.5 \mathrm{mg}$ [81]. At 1-month follow-up there was no difference between any of the etanercept groups and placebo. The 2nd article, also an RCT (Jadad score $=4$ ), compared 2 groups. The control group had $10 \mathrm{mg}$ bupivacaine infiltrated intradiscally and the other group had $10 \mathrm{mg}$ etanercept introduced in addition to that [82]. The study showed lower NRS scores from one to 4-week follow-up in the etanercept group but this difference disappeared at 8-week follow-up. Intradiscal etanercept seems to provide short term pain relief at best.

\section{Discussion}

As presented in our topical review, most of the studies on percutaneous treatments to discogenic pain are observational in nature. Only 7 out of more than 40 articles presented are RCTs. Though all are of reasonable to good quality (Jadad score all $\geq 3$ ), 5 out of 7 either did not calculate a sample size or did not meet it at the end of the study $[14,32,43,46,83]$. As such, the negative results obtained in the study could have been due to a lack of power. The difficulty of obtaining a proper blinded control group may also be a reason for the lack of RCTs as subjecting patients to a sham interventional procedure is neither palatable to patients and ethical boards.

The assessment of the various modalities is dependent largely on the results of prospective observational studies with all their inherent biases. As such, it is difficult for any modality to have a strong positive recommendation and none were found in our review. Even among the modalities with a weakly positive recommendation i.e. biacuplasty and $\mathrm{MB}$, more well conducted studies are certainly needed. IDET has the most number of publications though most of it is observational in nature. As mentioned above, 1 RCT was a negative study and the other RCT showed a slight advantage of IDET over placebo in well selected patients.

$\mathrm{MB}$ and biacuplasty are still in its infancy as compared to IDET but the initial results show promise. More evidence will be 
needed to ascertain their role in the treatment of discogenic pain. Though the mechanism of action of nucleoplasty for discogenic LBP is still in doubt and with some of the trials not fulfilling IASP criteria, all the observational studies show a positive result. More literature specifically addressing nucleoplasty for the management of discogenic LBP are needed to evaluate if it is a viable treatment option.

For the other modalities, it has been shown in this article that intradiscal steroids, DiscTRODE, intradiscal RF and L2 blockade/RF are not effective and there are better alternatives in the treatment of discogenic LBP. Intradiscal pRF has conflicting results and the methodology differs substantially between the studies, making it difficult to evaluate and should only be used in the context of a study. Rami communicantes RF only has 1 study in a very select group of patients and so no conclusions can be made on this modality.

It should be remembered that in this group of patients that have failed conservative management of discogenic LBP, the options for treatment are limited. Fusion surgery for this condition is not without controversy $[84,85]$ and its complications significant. However, allowing the patients to continue on long-term analgesics with its attendant side effects is not optimal, and many of these patients will still have significant disability [86]. Percutaneous treatments may allow a subset of these patients to have a significant improvement and the risk of complications as compared to surgery is much lower [87-90]. It is therefore critical to appraise the evidence for such modalities and adhere to strict patient selection. The limitations of this article are that only literature in PubMed and published in English were considered [91,92]. A broad overview, though not exhaustive, of all available percutaneous treatments for discogenic back pain has been discussed in sufficient detail to identify a need to have better designed studies and modalities for the indication of discogenic back pain [93-95].

\section{Conclusion}

Biacuplasty and intradiscal MB have a weakly positive recommendation for the treatment of discogenic pain. Nucleoplasty may potentially be a viable treatment though more evidence and basic research is needed. The evidence for IDET is equivocal. There are negative recommendations for intradiscal steroids, intradiscal RF, DiscTRODE or L2 blocks/ RF. Future trials on discogenic pain should ensure that the IASP definition of discogenic pain is adhered to and the methodology of confirming the diagnosis of discogenic pain clearly elucidated.

\section{References}

1. Hoy D, March L, Brooks P, Blyth F, Woolf A, et al. (2014) The global burden of low back pain: estimates from the Global Burden of Disease 2010 study. Ann Rheum Dis 73(6): 968-974.

2. DePalma MJ, Ketchum JM, Saullo T (2011) What is the source of chronic low back pain and does age play a role? Pain Med 12(2): 224-233.
3. Bogduk N (1983) The innervation of the lumbar spine. Spine 8(3): 286-293.

4. Freemont AJ, Peacock TE, Goupille P, Hoyland JA, O’Brien J, et al. (Nerve in growth into diseased intervertebral disc in chronic back pain. Lancet 350(9072): 178-181.

5. Coppes MH, Marani E, Thomeer RT, Groen GJ (1997) Innervation of "painful" lumbar discs. Spine 22(20): 2342-2349.

6. Coppes MH, Marani E, Thomeer RT, Oudega M, Groen GJ (1990) Innervation of annulus fibrosis in low back pain. Lancet 336(8708): 189-190.

7. Peng B, Wu W, Hou S, Li P, Zhang C, et al. (2005) The pathogenesis of discogenic low back pain. J Bone Joint Surg Br 87(1): 62-67.

8. Ohtori S, Inoue G, Miyagi M, Takahashi K (2015) Pathomechanisms of discogenic low back pain in humans and animal models. Spine J 15(6): 1347-1355.

9. Burke JG, Watson RW, McCormack D, Dowling FE, Walsh MG, et al. (2002) Intervertebral discs which cause low back pain secrete high levels of proinflammatory mediators. J Bone Joint Surg Br 84(2): 196201.

10. IASP Classification of Chronic Pain, Second Edition Revised (2018) IASP Washington DC, USA.

11. Buirski G, Silberstein M (1993) The symptomatic lumbar disc in patients with low-back pain. Magnetic resonance imaging appearances in both a symptomatic and control population. Spine 18(13): 18081811.

12. Alamin TF, Kim MJ, Agarwal V (2011) Provocative lumbar discography versus functional anesthetic discography: a comparison of the results of two different diagnostic techniques in 52 patients with chronic low back pain. Spine J 11(8): 756-765.

13. Ohtori S, Kinoshita T, Yamashita M, Inoue G, Yamauchi K, et al. (2009) Results of surgery for discogenic low back pain: a randomized study using discography versus discoblock for diagnosis. Spine 34(13): 1345-1348.

14. Barendse GA, van Den Berg SG, Kessels AH, Weber WE, van Kleef M Randomized controlled trial of percutaneous intradiscal radiofrequency thermocoagulation for chronic discogenic back pain: lack of effect from a 90-second 70 C lesion. Spine 26(3): 287-292.

15. Fukui S, Nitta K, Iwashita N, Tomie H, Nosaka S, et al. (2013) Intradiscal pulsed radiofrequency for chronic lumbar discogenic low back pain: a one year prospective outcome study using discoblock for diagnosis. Pain physician 16(4): E435-E42.

16. Fukui S, Nitta K, Iwashita N, Tomie H, Nosaka S, et al. (2012) Results of intradiscal pulsed radiofrequency for lumbar discogenic pain: comparison with intradiscal electrothermal therapy. The Korean J Pain 25(3): 155-160.

17. Van Kleef M, Barendse G, Wilmink J, Lousberg R, Bulstra S, et al. (1996) Percutaneous intradiscal radio-frequency thermo coagulation in chronic non-specific low back pain. The Pain Clinic 9(3): 259-268.

18. Bogduk N (2004) Provocative Discography: Lumbar Disc Stimulation. In: Bogduk N (Ed.), Practice Guidelines for Spinal Diagnostic and Treatment Procedures. International Spine Intervention Society, San Francisco, California, USA, p. 20-46.

19. Derby R, Lee SH, Kim BJ, Chen Y, Aprill C, et al. (2005) Pressurecontrolled lumbar discography in volunteers without low back symptoms. Pain Med 6(3): 213-221.

20. Feffer HL (1969) Therapeutic intradiscal hydrocortisone. A long-term study. Clin Orthop Relat Res 67: 100-104. 
21. Simmons JW, McMillin JN, Emery SF, Kimmich SJ (1992) Intradiscal steroids. A prospective double-blind clinical trial. Spine 17(6): S172-S175.

22. Cao P, Jiang L, Zhuang C, Yang Y, Zhang Z, et al. (2011) Intradiscal injection therapy for degenerative chronic discogenic low back pain with end plate Modic changes. Spine J 11(2): 100-106.

23. Buttermann GR (2004) The effect of spinal steroid injections for degenerative disc disease. The spine journal: official journal of the North American Spine Society 4(5): 495-505.

24. Biyani A, Andersson GB, Chaudhary H, An HS (2003) Intradiscal electrothermal therapy: a treatment option in patients with internal disc disruption. Spine 28(15): S8-S14.

25. Bogduk N, Karasek M (2002) Two-year follow-up of a controlled trial of intradiscal electrothermal anuloplasty for chronic low back pain resulting from internal disc disruption. Spine J 2(5): 343-350.

26. Karasek M, Bogduk N (2000) Twelve-month follow-up of a controlled trial of intradiscal thermal anuloplasty for back pain due to internal disc disruption. Spine 25(20): 2601-2607.

27. Saal JS, Saal JA (2000) Management of chronic discogenic low back pain with a thermal intradiscal catheter. A preliminary report. Spine 25(3): 382-388.

28. Saal JA, Saal JS (2002) Intradiscal electrothermal treatment for chronic discogenic low back pain: prospective outcome study with a minimum 2-year follow-up. Spine 27(9): 966-973.

29. Davis TT, Delamarter RB, Sra P, Goldstein TB (2004) The IDET procedure for chronic discogenic low back pain. Spine 29(7): 752-756.

30. Freedman BA, Cohen SP, Kuklo TR, Lehman RA, Larkin P, et al. (2003) Intradiscal electrothermal therapy (IDET) for chronic low back pain in active-duty soldiers: 2-year follow-up. Spine J 3(6): 502-509.

31. Spruit M, Jacobs WC (2002) Pain and function after intradiscal electrothermal treatment (IDET) for symptomatic lumbar disc degeneration. European spine journal: official publication of the European Spine Society, the European Spinal Deformity Society, and the European Section of the Cervical Spine Research Society. 11(6): 589-593.

32. Pauza KJ, Howell S, Dreyfuss P, Peloza JH, Dawson K, et al. (2004) A randomized, placebo-controlled trial of intradiscal electrothermal therapy for the treatment of discogenic low back pain. Spine J 4(1): 27-35.

33. Freeman BJ, Fraser RD, Cain CM, Hall DJ, Chapple DC (2005) A randomized, double-blind, controlled trial: intradiscal electrothermal therapy versus placebo for the treatment of chronic discogenic low back pain. Spine 30(21): 2369-2377.

34. Ackerman WE (2002) Cauda equina syndrome after intradiscal electrothermal therapy. Regional anesthesia and pain medicine. Regional Anesthesia and Pain Medicine 27(6): 622.

35. Hsia AW, Isaac K, Katz JS. Cauda equina syndrome from intradiscal electrothermal therapy. Neurology 55(2): 320.

36. Cohen SP, Larkin T, Polly DW (2002) A giant herniated disc following intradiscal electrothermal therapy. Clinical Spine Surgery 15(6): 537541.

37. Cohen SP, Larkin T, Abdi S, Chang A, Stojanovic M (1976) Risk factors for failure and complications of intradiscal electrothermal therapy: a pilot study. Spine 28(11): 1142-1147.

38. Djurasovic M, Glassman SD, Dimar JR, Johnson JR (2002) Vertebral osteonecrosis associated with the use of intradiscal electrothermal therapy: a case report. Spine 27(13): E325-E328.
39. Scholl BM, Theiss SM, Lopez-Ben R, Kraft M (2003) Vertebral osteonecrosis related to intradiscal electrothermal therapy: a case report. Spine 28(9): E161-E164.

40. Orr RD, Thomas SA (2005) Intradural migration of broken IDET catheter causing a radiculopathy. J Spinal Disord Tech 18(2): 185-187.

41. Finch PM, Price LM, Drummond PD (2005) Radiofrequency heating of painful annular disruptions: one-year outcomes. J Spinal Disord Tech 18(1): 6-13.

42. Kapural L, Hayek S, Malak O, Arrigain S, Mekhail N (2005) Intradiscal thermal annuloplasty versus intradiscal radiofrequency ablation for the treatment of discogenic pain: a prospective matched control trial. Pain Med 6(6): 425-431.

43. Kvarstein G, Mawe L, Indahl A, Hol PK, Tennoe B, et al. (2009) A randomized double-blind controlled trial of intra-annular radiofrequency thermal disc therapy--a 12-month follow-up. Pain. 145(3): 279-286.

44. Tang YZ, Ni JX, An JX (2013) Complex regional pain syndrome type I following discTRODE radiofrequency treated with continuous lumbar sympathetic trunk block using patient-controlled analgesia. Pain Med 14(2): 309-310.

45. Sluijter ME (1996) Percutaneous intradiscal radio-frequency thermocoagulation. Spine 21(4): 528-529.

46. Ercelen O, Bulutcu E, Oktenoglu T, Sasani M, Bozkus H, et al. (2003) Radiofrequency lesioning using two different time modalities for the treatment of lumbar discogenic pain: a randomized trial. Spine 28(17): 1922-1927.

47. Chua NH, Vissers KC, Sluijter ME (2011) Pulsed radiofrequency treatment in interventional pain management: mechanisms and potential indications-a review. Acta neurochirurgica 153(4): 763-771.

48. Teixeira A, Sluijter ME (2006) Intradiscal high-voltage, long-duration pulsed radiofrequency for discogenic pain: a preliminary report. Pain Med 7(5): 424-428.

49. Jung YJ, Lee DG, Cho YW, Ahn SH (2012) Effect of intradiscal monopolar pulsed radiofrequency on chronic discogenic back pain diagnosed by pressure-controlled provocative discography: a one year prospective study. Annals of rehabilitation medicine 36(5): 648-656.

50. Rohof O (2012) Intradiscal pulsed radiofrequency application following provocative discography for the management of degenerative disc disease and concordant pain: a pilot study. Pain Pract 12(5): 342-349.

51. Oh WS, Shim JC (2004) A randomized controlled trial of radiofrequency denervation of the ramus communicans nerve for chronic discogenic low back pain. Clin J Pain 20(1): 55-60.

52. Nakamura SI, Takahashi K, Takahashi Y, Yamagata M, et al. (1996) The afferent pathways of discogenic low-back pain. Evaluation of L2 spinal nerve infiltration. J Bone Joint Surg Br 78(4): 606-612.

53. Simopoulos TT, Malik AB, Sial KA, Elkersh M, Bajwa ZH (2005) Radiofrequency lesioning of the $\mathrm{L} 2$ ramus communicans in managing discogenic low back pain. Pain physician 8(1): 61-65.

54. Richardson J, Collinghan N, Scally AJ, Gupta S (2009) Bilateral L1 and L2 dorsal root ganglion blocks for discogenic low-back pain. Br J Anaesth 103(3): 416-419.

55. Sharps LS, Isaac Z (2002) Percutaneous disc decompression using nucleoplasty. Pain physician 5(2): 121-126.

56. Singh V, Piryani C, Liao K (2004) Role of percutaneous disc decompression using coblation in managing chronic discogenic low back pain: a prospective, observational study. Pain physician $7(4)$ : 419-425. 
57. Singh V, Piryani C, Liao K (2003) Evaluation of percutaneous disc decompression using coblation in chronic back pain with or without leg pain. Pain physician 6(3): 273-280.

58. Singh V, Piryani C, Liao K, Nieschulz S (2002) Percutaneous disc decompression using coblation (nucleoplasty) in the treatment of chronic discogenic pain. Pain physician 5(3): 250-259.

59. Reddy AS, Loh S, Cutts J, Rachlin J, Hirsch JA (2005) New approach to the management of acute disc herniation. Pain physician 8(4): 385390.

60. Masala S, Massari F, Fabiano S, Ursone A, Fiori R, et al. (2007) Nucleoplasty in the treatment of lumbar diskogenic back pain: one year follow-up. Cardiovascular and interventional Radiology. 30(3): 426-432.

61. Kumar NS, Shah SM, Tan BW, Juned S, Yao K (2013) Discogenic axial back pain: is there a role for nucleoplasty? Asian spine journal 7(4): 314-321.

62. He L, Hu X, Tang Y, Li X, Zheng S, et al. (2015) Efficacy of coblation annuloplasty in discogenic low back pain: a prospective observational study. Medicine 94(19): 1-6.

63. Ong D, Chua NH, Vissers K (2014) Percutaneous Disc Decompression for Lumbar Radicular Pain: A Review Article. Pain pract 16(1): 111126.

64. Petersohn JD, Conquergood LR, Leung M (2008) Acute histologic effects and thermal distribution profile of disc biacuplasty using a novel water-cooled bipolar electrode system in an in vivo porcine model. Pain Med 9(1): 26-32.

65. Pauza K (2008) Cadaveric intervertebral disc temperature mapping during disc biacuplasty. Pain physician 11(5): 669-676.

66. Kapural L, Mekhail N (2007) Novel intradiscal biacuplasty (IDB) for the treatment of lumbar discogenic pain. Pain pract 7(2): 130-134.

67. Kapural L, Ng A, Dalton J, Mascha E, Kapural M, et al. (2008) Intervertebral disc biacuplasty for the treatment of lumbar discogenic pain: results of a six-month follow-up. Pain Med 9(1): 60-67.

68. Karaman H, Tufek A, Kavak GO, Kaya S, Yildirim ZB, et al. (2010) 6-month results of TransDiscal Biacuplasty on patients with discogenic low back pain: preliminary findings. Int J Med Sci 8(1): 1-8.

69. Kapural L, Vrooman B, Sarwar S, Krizanac-Bengez L, Rauck R, et al. (2013) A randomized, placebo-controlled trial of transdiscal radiofrequency, biacuplasty for treatment of discogenic lower back pain. Pain Med 14(3): 362-373.

70. Kapural L, Vrooman B, Sarwar S, Krizanac-Bengez L, Rauck R, et al. (2015) Radiofrequency intradiscal biacuplasty for treatment of discogenic lower back pain: a 12-month follow-up. Pain Med 16(3): 425-431.

71. Peng B, Pang X, Wu Y, Zhao C, Song X (2010) A randomized placebocontrolled trial of intradiscal methylene blue injection for the treatment of chronic discogenic low back pain. Pain 149(1): 124-129.

72. Peng B, Zhang Y, Hou S, Wu W, Fu X (2007) Intradiscal methylene blue injection for the treatment of chronic discogenic low back pain. European spine journal: official publication of the European Spine Society, the European Spinal Deformity Society, and the European Section of the Cervical Spine Research Society 16(1): 33-38.

73. Liu GZ, Ishihara H, Osada R, Kimura T, Tsuji H (2001) Nitric oxide mediates the change of proteoglycan synthesis in the human lumbar intervertebral disc in response to hydrostatic pressure. Spine 26(2): 134-141.

74. Mayer B, Brunner F, Schmidt K (1993) Inhibition of nitric oxide synthesis by methylene blue. Biochem Pharmacol 45(2): 367-374.
75. Gupta G, Radhakrishna M, Chankowsky J, Asenjo JF (2012) Methylene blue in the treatment of discogenic low back pain. Pain physician 15(4): 333-338.

76. Kim SH, Ahn SH, Cho YW, Lee DG (2012) Effect of Intradiscal Methylene Blue Injection for the Chronic Discogenic Low Back Pain: One Year Prospective Follow-up Study. Annals of rehabilitation medicine 36(5): 657-664.

77. Kallewaard JW, Geurts JW, Kessels A, Willems P, van Santbrink H, et al. (2015) Efficacy, Safety, and Predictors of Intradiscal Methylene Blue Injection for Discogenic Low Back Pain: Results of a Multicenter Prospective Clinical Series. Pain Pract 16(4): 405-412.

78. Lee SH, Derby R, Sul D, Hong YK, Ha KW, et al. (2015) Effectiveness of a new navigable percutaneous disc decompression device (L'DISQ) in patients with lumbar discogenic pain. Pain Med 16(2): 266-273.

79. Iwatsuki K, Yoshimine T, Umegaki M, Yoshimura K, Ohnishi Y, et al. (2011) Percutaneous diode laser irradiation for lumbar discogenic pain: a clinical study. Photomedicine and laser surgery 29(7): 459-463.

80. Black W, Fejos AS, Choy DS (2004) Percutaneous laser disc decompression in the treatment of discogenic back pain. Photomed Laser Surg 22(5): 431-433.

81. Cohen SP, Wenzell D, Hurley RW, Kurihara C, Buckenmaier CC, et al. (2007) A double-blind, placebo-controlled, dose-response pilot study evaluating intradiscal etanercept in patients with chronic discogenic low back pain or lumbosacral radiculopathy. Anesthesiology 107(1): 99-105.

82. Sainoh T, Orita S, Miyagi M, Inoue G, Kamoda H, et al. (2015) Single Intradiscal Administration of the Tumor Necrosis Factor-Alpha Inhibitor, Etanercept, for Patients with Discogenic Low Back Pain. Pain Med 17(1): 40-45.

83. Kapural L, Mekhail N (2006) A randomized, double-blind, controlled trial: intradiscal electrothermal therapy versus placebo for the treatment of chronic discogenic low back pain. Spine 31(14): 16361638.

84. Wang X, Wanyan P, Tian JH, Hu L (2014) Meta-analysis of randomized trials comparing fusion surgery to non-surgical treatment for discogenic chronic low back pain. J Back Musculoskelet Rehabil 28(4): 621-627.

85. Bydon M, De la Garza-Ramos R, Macki M, Baker A, Gokaslan AK, et al. (2014) Lumbar fusion versus nonoperative management for treatment of discogenic low back pain: a systematic review and meta-analysis of randomized controlled trials. J Spinal Disord Tech 27(5): 297-304.

86. Derby R, Eek B, Chen Y, O’Neill C, Ryan D (2000) Intradiscal Electrothermal Annuloplasty (IDET): A Novel Approach for Treating Chronic Discogenic Back Pain. Neuromodulation 3(2): 82-88.

87. Saal JA, Saal JS (2000) Intradiscal electrothermal treatment for chronic discogenic low back pain: a prospective outcome study with minimum 1-year follow-up. Spine 25(20): 2622-2627.

88. Singh V (2000) Intradiscal electrothermal therapy: a preliminary report. Pain physician 3(4): 367-373.

89. Gerszten PC, Welch WC, McGrath PM, Willis SL (2002) A prospective outcomes study of patients undergoing intradiscal electrothermy (IDET) for chronic low back pain. Pain physician 5(4): 360-364.

90. Lee MS, Cooper G, Lutz GE, Lutz C, Hong HM (2003) Intradiscal electrothermal therapy (IDET) for treatment of chronic lumbar discogenic pain: a minimum 2-year clinical outcome study. Pain physician 6(4): 443-448.

91. Maurer P, Block JE, Squillante D (2008) Intradiscal electrothermal therapy (IDET) provides effective symptom relief in patients with discogenic low back pain. J Spinal Disord Tech 21(1): 55-62. 
92. Nunley PD, Jawahar A, Brandao SM, Wilkinson KM (2008) Intradiscal electrothermal therapy (IDET) for low back pain in worker's compensation patients: can it provide a potential answer? Long-term results. J Spinal Disord Tech 21(1): 11-18.

93. Assietti R, Morosi M, Block JE (2010) Intradiscal electrothermal therapy for symptomatic internal disc disruption: 24-month results and predictors of clinical success. J Neurosurg Spine 12(3): 320-326.
94. Yakovlev A, Tamimi MA, Liang H, Eristavi M (2007) Outcomes of percutaneous disc decompression utilizing nucleoplasty for the treatment of chronic discogenic pain. Pain physician 10(2): 319-328.

95. Zhu H, Zhou XZ, Cheng MH, Shen YX, Dong QR (2011) The efficacy of coblation nucleoplasty for protrusion of lumbar intervertebral disc at a two-year follow-up. International orthopaedics 35(11): 1677-1682.

\section{Your next submission with Juniper Publishers will reach you the below assets}

- Quality Editorial service

- Swift Peer Review

- Reprints availability

- E-prints Service

- Manuscript Podcast for convenient understanding

- Global attainment for your research

- Manuscript accessibility in different formats

( Pdf, E-pub, Full Text, Audio)

- Unceasing customer service

Track the below URL for one-step submission https://juniperpublishers.com/online-submission.php 